\title{
Susceptibility of non-native invasive plants to novel pathogen attack - do plant traits matter?
}

\author{
Catherine Fahey ${ }^{1}$, Akihiro Koyama ${ }^{2}$, and Pedro Madeira Antunes ${ }^{1}$ \\ ${ }^{1}$ Algoma University \\ ${ }^{2}$ Affiliation not available
}

August 12, 2020

\begin{abstract}
1. Invasive plants are considered major threats to biodiversity globally; however, our understanding of the long-term dynamics of invasion remains limited. 2. Over time, invasive plants can accumulate pathogens capable of causing population declines because invaders have a greater chance of encountering such pathogens as they spread and native pathogens adapt to use invasive plants as a resource over time. However, reports typically focus on individual species and ecologists lack a synthesis approach capable of predicting pathogen susceptibility in plant invaders. 3. Pathogen resistance and tolerance are tightly coupled to plant traits, which we suggest can provide a framework for understanding and predicting novel pathogen accumulation. 4 . We reviewed the literature to synthesize plant traits associated with pathogen susceptibility and to determine the prevalence of novel pathogen accumulation on invasive plants. We then used these data and applied a multivariate model to associate plant traits with pathogen effects to predict pathogen susceptibility of invasive plants. Finally, we provide directions for future research. 5 . Considering the emergence of trait-based approaches, comprehensive databases, and new data on individual invasions, advances in our understanding of invasive plant-pathogen interactions can lead to breakthroughs both at fundamental and management decision-making levels.
\end{abstract}

\section{Introduction}

Non-native invasive species (hereafter invasive species) are considered one of the most important threats to biodiversity today (Vitouseket al. 1997; Pimentel et al. 2005; Simberloff \& Rejmanek 2011; Vilà et al. 2011; Doherty et al. 2016; Mollotet al. 2017; Howard et al. 2020) . A leading hypothesis to explain why certain introduced species become invasive is the Enemy Release hypothesis, stating that invasive plants are released from their specialized enemies from their native ranges (Keane \& Crawley 2002; Mitchell \& Power 2003; Colautti et al. 2004; Torchin \& Mitchell 2004), but see (van Kleunen \& Fischer 2009). However, over the invader's residence time in the introduced range, such 'enemy release' is expected to decrease as a factor driving invasibility (Diezet al. 2010; Mitchell et al. 2010; Gruntman et al.2017). From an evolutionary perspective, native pathogens may adapt to use invaders as a resource over time (Parker \& Gilbert 2004; Mitchell et al. 2010). Furthermore, as an invader spreads in the introduced range, it encounters a greater number of novel pathogens and has a greater chance of encountering pathogens for which it is a competent host (Mitchellet al. 2010; Flory \& Clay 2013).

Evidence shows invasive plants can undergo rapid evolution in the introduced range (Prentiset al. 2008). For example, the Evolution of Increased Competitive Ability (EICA) hypothesis suggests that reduced enemy pressure in the introduced range leads to a change in allocation from defense to growth/competitive traits (Blossey \& Notzold 1995; Joshi \& Vrieling 2005). This reduction in allocation to defense could predispose invaders to enemy attack as novel enemies are encountered and adapt to invader presence in the introduced range. The Enemy Release and EICA hypotheses have been more thoroughly investigated for herbivores than for pathogens; however, evidence suggests that pathogens have the potential to regulate the long-term 
dynamics of plant invasions (Handley et al. 2008). Nevertheless, it remains unclear how common pathogenmediated population decline is among invasive plants and how these interactions change over time (Flory \& Clay 2013).

As these novel interactions occur, the question arises; can we make predictions about which invasive plants are most susceptible or resistant to pathogen related declines? Plant functional traits are likely to be a major driver of the variation in susceptibility to pathogens. Plant traits covary along specific axes related to growth rate, reproductive strategy, and defense due to necessary trade-offs in allocation making up the 'fast-slow' plant economic spectrum (Wright et al. 2004; Reich 2014; Salguero-Gómez et al. 2016). At one end of the spectrum, plants with an acquisitive strategy have rapid growth rates and photosynthesis rates, and high tissue nutrient content and specific leaf area, but short leaf lifespan and plant longevity, while at the other end conservative plants have the opposite traits (Cronin et al.2014; Welsh et al. 2016). It is also expected that plants at the acquisitive end of this spectrum will expend less on defense against enemies compared to conservative plants (Endara \& Coley 2011; Parker \& Gilbert 2018). Within Grime's C-S-R model, fast growing competitive species adapted to high nutrient conditions were found to support more pathogens compared to stress tolerators and these acquisitive species benefited more from enemy release in the introduced range (Blumenthal et al. 2009). Specifically, acquisitive plant species produce less costly tissues with high turnover rates and lower investment in defense, thereby allowing for greater enemy attack with lower fitness cost (Coley et al.1985; Endara \& Coley 2011). Cronin, Rúa, and Mitchell (2014) showed that plant acquisition strategy was connected to resistance of grass species to viral infection. Therefore, we propose that invasive plant traits can aid in understanding the long-term dynamics of invasions due to associations of plant traits with susceptibility to novel pathogen attack. In this review, we identify which plant traits confer the ability to either resist, tolerate, or escape pathogens, and explore how such knowledge can help us make quantitative predictions about which invaders are most likely to be susceptible.

\section{TEXT BOX 1 - Traits associated with pathogen susceptibility}

Plant traits associated with pathogen resistance, tolerance, and escape will determine susceptibility of invasive plants to novel pathogen accumulation. Resistance is the ability of host plants to inhibit or control pathogen infection, while tolerance is the ability of host plants to adjust their biomass or fitness post pathogen infection to reduce impacts, and escape refers to plant avoidance of contact with pathogens (Veresoglouet al. 2013). Resistance helps host plants prevent or slow down accumulation of pathogens, and tolerance alleviates reduction in fitness with pathogen infection. Many plant traits are associated with resistance and tolerance to pathogens and these can determine long-term population dynamics including population declines.

Here, we review plant traits associated with pathogen susceptibility, which may help predict which invasive plants are more susceptible to novel pathogen attack. We used the TRY database (version 5) to review a broad range of plant traits and organized them into general categories of traits (e.g. leaf traits, root traits, growth traits) (Kattge et al. 2011). We then searched the literature for references showing how these traits can influence pathogen susceptibility (Table 1 and Figure 1). Many of these traits are correlated with one another and can vary along the plant economic spectrum and along with growth-defense trade-offs; therefore, it is not always possible to separate these as the direct drivers of pathogen susceptibility but they can be useful for predictive purposes (Herms \& Mattson 1992; Reich 2014; Parker \& Gilbert 2018). Below, we first discuss evidence for pathogen resistance, tolerance, and escape with respect to each of the categories of traits. Next, we review examples of pathogen accumulation on invasive plants, and finally propose a framework aimed at explicitly accounting for the relative importance of traits for pathogen susceptibility.

Size/ growth traits

It has been observed that faster-growing species experience greater pathogen infection, indicating a trade-off between growth and pathogen resistance (Hoffland et al. 1996; Blumenthal et al. 2009; Parker \& Gilbert 2018). Some evidence suggests, taller plants and plants with faster vertical elongation may be more susceptible to pathogens (Marquis et al.2001; Robert et al. 2018). There is some evidence that invasive plants have, on average, faster growth rate and larger size than non-invasive species which could predispose them to pathogen 
attack (van Kleunen et al.2010).

Chemical defense

Growth is typically negatively correlated with chemical defense allocation because of the cost of secondary metabolite production (Herms \& Mattson 1992). Plants produce a wide variety of defense chemicals that can inhibit pathogens (Bednarek \& Osbourn 2009). For example, the invader Solidago canadensis can suppress soil pathogens via allelochemicals including flavones, phenolics, and saponins (Zhang et al.2009, 2010). While some species are known to produce relatively high concentrations of these compounds, comparisons between invaders with high and low production of these compounds is required to understand cost-benefit relative to other defense traits.

\section{Plant immune response}

Defense priming is defined as the conditioning of plants to respond physiologically to external stresses such as pathogen infection (Mauch-Mani \& Mauch 2005; Conrath et al. 2006). Systemic acquired resistance (SAR) is a phenomenon in which pathogenesis on a part of a plant activates defense in the whole plant via a suite of chemical signals (Malamyet al. 1990; Mauch-Mani \& Mauch 2005; Conrath et al.2006; Dempsey $\&$ Klessig 2012). Thus, priming allows plants to respond rapidly to future attack and SAR activates plant defense against attack on plant tissues that have not yet been affected. Defense priming has been found to be a widespread ecological phenomenon (Karban 2011); however, quantitative comparisons of different plant species, including invasive species, has not yet been conducted.

Plant life cycle

Plant life cycle (i.e., annual, biennial, and perennial) can influence susceptibility of plants to pathogens (Clay 1995). Certain pathogens are more likely to infect and persist in perennial than annual plant populations because annual plants do not have overlapping generations, so this advantage of annual plant species is specific to horizontally transmitted pathogens. Whereas, pathogens that depend on alternative mechanisms to persist such as vertical transmission (i.e., transmission from seeds to mature plants, instead of horizontal transmission between plants), free-living infective stages, and alternative hosts would persist among annual plant species (Thrall et al.1993; Borer et al. 2007). To our knowledge, no studies have determined the prevalence of pathogens in plant species with different life-cycles.

\section{Reproductive traits}

Life history strategies related to reproduction are similarly connected with trade-offs in allocation patterns. For example, larger seeds and those that require longer germination times tend to have increased pathogen susceptibility (Pringle et al. 2007; Beckman \& Muller-Landau 2011; Beckstead et al. 2014; Domínguez-Begines et al. 2020). However, seed traits related to dormancy (e.g. physical barriers, chemical defense, association with beneficial microbes, and germination time) are associated with resistance to pathogen infection (Dalling et al.2011). These seed defense syndromes provide a framework to study if seed traits of invasive plants influence the probability of pathogen accumulation. Seed and plant traits such as seed mass, plant height, and dispersal mode also influence seed dispersal distance (Thomson et al.2011; Tamme et al. 2014), which is an important determinant of density dependent pathogen effects and negative plant-soil feedbacks (Augspurger \& Kelly 1984). Foraging arthropods, including pollinators and herbivores, can transmit pathogens among plants (Durrer \& Schmid-Hempel 1994). Plants with more attractive flowers (e.g, higher nectar production) may thus be particularly susceptible to pathogen attack (Rocheet al. 1995; Shykoff \& Bucheli 1995; Shykoff et al. 1996; Ferrari et al. 2007).

\section{Leaf characteristics}

Leaf traits vary along the leaf economic spectrum from costly leaves with long lifespan and high leaf mass per area (LMA) to quick-return, short-lived leaves with high photosynthetic rates and nitrogen content (Wright et al. 2004). Species that invest in quick-return leaves are relatively more susceptible to pathogen attack (Welsh et al. 2016). However, quick-return leaves may also have faster leaf expansion rate than well 
defended slow-return leaves, which has been associated with lower pathogen damage, indicating a possible trade-off (Marquis et al.2001). Plant species that minimize potential points of entry for pathogens such as stomata number, invest in leaf defense traits that protect against pathogens ( e.g., thickened cuticle and higher trichome density) and hold water to a minimum (e.g., hydrophobic leaves with low surface moisture) are less susceptible to pathogen attack (Bradley et al. 2003; Chattopadhyay et al. 2011; Serrano et al.2014). Data on leaf traits and pathogen susceptibility have focused specifically on a few species and it is not clear to what extent they are applicable to a wider variety of species, including natives versus non-natives.

Fungal endophytes have also been shown to provide protection against pathogens (Dini-Andreote 2020). For example, the mutualism between temperate grasses and fungal endophytes such as Epichloe spp. can defend against pathogens, however more research on host-endophyte-pathogens interaction is needed in the context of invasions (Clay \& Schardl 2002; Schardl et al. 2004). For example, we lack biogeographic home and away comparisons between populations for the presence and functional ecology of endophytes. We also lack an understanding of to what extent endophytes of non-native species contribute to competition with native plants through increased pathogen resistance and tolerance of their hosts.

\section{Root traits}

Plant roots, like leaves, are also thought to follow a root economic spectrum that influences soil pathogen susceptibility, but root systems are less well studied than aboveground traits and some evidence suggests that the root economic spectrum is only partially correlated with the leaf economic spectrum (Kramer-Walter et al. 2016; Laliberte 2017). Larger root systems can improve disease tolerance of plants when roots serve as storage organs for regrowth after damage/defoliation (Erbet al. 2009). As seen with leaves, faster growing roots with high turnover rates are less susceptible to pathogen attack (Yanai \& Eissenstat 2002; Atucha et al. 2014), and root surface area and secondary root diameter have been shown to be positively correlated with disease resistance (Sollaet al. 2011; Singh et al. 2019). There is limited information on the mechanisms driving these correlations and studies across a broad range of species are needed to determine the full range of variability in disease susceptibility.

It is well documented that arbuscular mycorrhizal (AM) colonization can protect plants from soil-borne pathogens (Borowicz 2001; Whipps 2004; Pozo \& Azcon-Aguilar 2007; Wehner et al.2011; Lewandowski et al. 2013). Potential mechanisms for mycorrhizal mediated pathogen protection include; 1 ) direct competition with or inhibition of pathogens (Newsham et al.1995); 2) promotion or changes in plant growth, nutrition, and morphology (Wehner et al. 2011); 3) modulation of biochemical plant defense (Van Wees et al.2008); and 4) facilitation of pathogen suppressive microbiomes (Whipps 2004). These mechanisms can be influenced by root architecture such as root branching (Sikes et al.2009; Maherali 2014). Ectomycorrhizal (ECM) fungi can also protect their hosts from pathogens and are thought to provide better protection against pathogens than AM fungi because of the sheath, hyphal network, and antimicrobial substances associated with ECM fungi (Garrett 1956; Marx 1972; Stack 1975; Duchesne et al. 1989). Evidence has been accumulating to suggest that ECM fungal protection against soil-borne pathogens can be a major mechanism behind more positive plant-soil feedbacks among ECM driving mono-specific stands of ECM compared to AM species (Connell \& Lowman 1989; Laliberte et al. 2015; Liang et al. 2020). These findings suggest that ECM invasive plants may be less susceptible to pathogens than AM or non-mycorrhizal invaders, provided they encounter compatible ECM fungi.

\section{Nutrient contents}

The range of fast-slow return trade-offs for plants is strongly related to nutrient regimes, where fast growing species are commonly adapted to nutrient rich sites (Wrightet al. 2004). However, few studies have compared interspecific variation in plant nutrient concentrations to pathogen attack (Marquis et al.2001). The majority of studies on the relationship between plant nutrient status and pathogenicity have focused on fertilization effects on agricultural crops, primarily for nitrogen (Walters \& Bingham 2007; Dordas 2008; Veresoglou et al. 2013). Nitrogen status can affect pathogen susceptibility of plants in two ways; plant tissue quality and production of secondary metabolites (Hoffland et al.2000). Nutrient rich tissues are often more susceptible 
to diseases either because they are less well defended or they are more nutrient dense for the pathogen; however, N-limitation can weaken plant immunity and may be a cue for development of disease symptoms by some pathogens (Snoeijers et al.2000). Results may differ when comparing nutrient content across species and fertilization effects on a single species. Hantsch et al. (2014) found no effect of tree species differences in foliar carbon and nitrogen on pathogen load, while prior studies on intraspecific variation showed higher leaf nitrogen was associated with increased disease (El-Hajj et al.2004; McElrone et al. 2005). Laliberte et al. (2015) proposed that there is a trade-off in phosphorus acquisition and soil pathogen attack suggesting that plants adapted for phosphorus limited soils have poorly defended roots. However, mycorrhizal associations may ameliorate such susceptibility.

\section{Context dependence}

Plant traits have been assessed for usefulness to predict invasibility of plants in introduced ranges (Lambdon \& Hulme 2006; Pyšek \& Richardson 2008; van Kleunen et al. 2010); however, conclusions are equivocal. Thompson \& Davis (2011) argue that invasive plants do not possess traits significantly different from native species, therefore, traits are not useful to predict invasibility of plants. In contrast, (van Kleunen et al. 2010; Van Kleunen et al. 2010)) oppose this argument. Recent studies concluded that it is challenging to use traits to predict invasibility of plants, in part, because it is context dependent; interaction between a trait and environmental factors most likely determines invasibility of a given non-native species (Alpert et al.2000; Leffler et al. 2014). Pyšek et al. (2012) concluded that traits of an invasive plant can be useful to assess their impacts on ecosystems, but this is also strongly context dependent. This likely also applies to traits determining pathogen susceptibility. For instance, a non-native plant may have a higher chance to be infected by pathogens if the introduced range has phylogenetically closely related species (Agrawal \& Kotanen 2003; Parker \& Gilbert 2007; Parker et al. 2015). We emphasize that the importance of plant traits may also be context dependent for predicting susceptibility of plants to pathogens.

Many invasive species tend to form near mono-specific patches, which is less common for native species (Burdon et al. 1989; Levine et al. 2003; Hejda et al. 2009). Studies have shown that density of host plant populations was positively correlated with disease levels in agricultural (Burdon \& Chilvers 1982) and natural systems (Cobb et al. 1982; Jennersten et al. 1983; Alexander 1984; Burdonet al. 1995). While this tendency of invasive species may in part be due to escape from enemies in the introduced range, it may also make them more susceptible to population decline if a compatible pathogen is encountered (Clay et al.2008; Mordecai 2011). This density-dependent pathogen severity suggests that invasive plants with high density may decline due to pathogens over the time.

Evolution of both non-native host plants (Maron et al. 2004) and pathogens (Parker \& Gilbert 2004) is another factor that may regulate susceptibility of plants to pathogens. Recent studies indicate that some invasive plants have the ability to rapidly adapt to new environments modifying their traits such as total biomass, SLA, or flowering time (Flory et al.2011b; Colautti \& Barrett 2013). Furthermore, levels of phenotypic plasticity and ontogenetic change in traits is another factor to consider in determining disease susceptibility (Boege et al. 2007).

There is unlikely a single predictor of pathogen accumulation and there will be context dependence complicating observed patterns. This context dependence may be related to different types of pathogens, species interactions, and/or environmental conditions. For example, it has been suggested that responses of pathogens to plant N status may depend on the types of pathogens (Hoffland et al.1999, 2000). High tissue N content is predicted to increase disease severity by obligate or biotrophic pathogens but reduce severity of facultative or necrotrophic pathogens (Hoffland et al. 2000; Dordas 2008; Veresoglou et al. 2013). Similarly, plant senescence is also related to different types of pathogens. Early senescence reduces impacts of biotrophic pathogens while delayed senescence acts as defense against necrotrophic pathogens (Häffner et al.2015). Furthermore, pathogen dispersal mode may influence relationships with plant traits. For example, taller plants may be more susceptible to wind dispersed pathogens, whereas plants with foliage low to the ground may be more affected by pathogens from the soil surface (Marquis et al. 2001; Robert et al. 2018; Vidal et al. 2018), suggesting that traits conferring tolerance, resistance, and escape may be pathogen dependent. 


\section{Evidence of invader decline}

To determine the prevalence of novel pathogen accumulation on invasive plants, we compiled examples of plant invader disease from the literature. We searched Web of Science with the following terms: ("plant inva*" OR "invasive plant*") AND (dieback* OR disease* OR pathogen* OR infect*) on March 16, 2020. This search produced 661 results. References cited in articles found through this search were also analyzed. The following conditions were required for inclusion: (1) the plant species must be considered non-native invasive (based on the CABI database or local invasive plant lists); (2) disease must have been observed on the invader in its non-native range; (3) the cause of the disease must have been identified by inoculating the invader with the pathogen and observing disease symptoms; and (4) the disease agent must be native to the non-native range of the plant invader or globally distributed. Because information on the natural ranges of plant diseases can be scarce, we included plant diseases where the available information suggests they are likely native, newly identified taxa on invaders in their non-native ranges, as well as globally distributed pathogens of unknown origin. While globally distributed pathogens may have encountered invasive plants in their native range, they are not subject to stochastic introduction processes as they are already widely distributed.

We found 20 invasive plant-pathogen combinations with 16 different invasive plant species experiencing native/novel pathogen effects from 17 unique pathogens (Table 2). The species of plants came from a wide variety of functional groups including grasses (3), forbs (6), shrubs/vines (4), leguminous shrubs (2), and a tree (1). Of these records, 13 were from North America, 2 from South Africa, 3 from Europe, and 2 from Australia. Seven of these examples had globally distributed pathogens of unknown origin and 13 were native or newly described pathogens. We recorded the approximate year of introduction of the plant invader and the year the pathogen was first observed on the invader. The amount of time for disease to develop on the invaders ranged from $\sim 60$ years to over 200 years, with the average approximately 120 years. This range is consistent with evidence of reduced enemy release after similar residence time (Hawkes 2007). It is possible that potential invaders that are impacted by native diseases after short residence time while still in the lag phase do not become problematic invaders.

Some of the pathogens in our survey had major impacts on invader populations in the field such as Pseudolagarobasidium acaciicolaon Acacia cyclops, while others showed high levels of pathogenicity in laboratory trials but had low to moderate effects in the field such as Erysiphe cruciferarum on Alliaria petiolata (Cipollini et al. 2020). There are a variety of reasons that effects in the field could be lower than in laboratory trials. For example, pathogen inoculum density in the field may be too low to cause severe disease symptoms (De la Cruz et al.2018), the pathogen may have poor dispersal ability in the field preventing widespread impacts on the invader, the pathogen may only cause symptoms in combination with certain environmental conditions making its impact variable either spatially or temporally (Aghighi et al.2014), or there may be differences in population level susceptibility of the invader (Meyeret al. 2001). While we focus primarily on interspecific differences in invader traits, it is also important to recognize that differences in population level susceptibility are also likely related to plant traits (Cipolliniet al. 2020). In some of the cases we identified, the pathogen is thought to be vectored by insects. For example, rose rosette disease is vectored by mites (Pemberton et al.2018) and Pseudomonas syringae pv. syringae disease on C.stoebe ssp. micranthos and Botryodiplodia theobromae on Mimosa pigra require wounding to infect plants and are thought to be associated with introduced biocontrol insects (Wilson \& Pitkethley 1992; Kearing 1996; Kearing et al. 1997). Plant traits related to defense against herbivores could also influence the interactions between invaders and insect vectors.

On the whole, we found relatively few examples of novel pathogen accumulation compared with the total number of invasive plant species, but our review also highlights areas where further research is needed. Additional cases of novel pathogen accumulation may exist that are not recorded in peer-reviewed literature, or are excluded from our review because, for example, it is difficult to identify the cause of decline or because of the limited information on the natural ranges of microbial pathogens (Aghighi et al. 2014). There are also strong geographic biases in the study of invasive plants and there could be additional cases of novel pathogen 
interactions in understudied regions (Pyšek et al. 2008). With these limitations in mind, how can we better allocate resources to predict what invasive species may be more susceptible to decline?

\section{Predicting pathogen susceptibility}

As a demonstration of how these data can be applied, we used the data collected on pathogen impacts on invasive plants in Table 2 and applied a multivariate model to associate plant traits with pathogen effects (Figure 2). We compiled trait data from the TRY database for each invader and then selected all the traits that were available for at least $70 \%$ of species. We then ran principal component analysis (PCA) with imputed data for missing values using the 'FactoMineR' and 'missMDA' packages in R (Lê et al. 2008; Josse et al. 2016). We calculated the pathogen effect as the relative difference in performance (e.g. survival, reproductive output, growth) between the control and pathogen infected plants averaged across all available studies of each plant-pathogen combination (Table S1). For studies that tested multiple pathogens on a single invader only the most pathogenic was used in the analysis. The pathogen effect was included as a supplementary variable (i.e. not used in the calculation of the axes but projected over the trait axes) to the PCA. For three species in our dataset a quantitative pathogen effect was not available (Ambrosia artemisiifolia, Asclepias syriaca, and Centaurea diffusa), so we added these as supplemental species to the PCA based on their trait values as a demonstration of how trait data can be used to predict pathogen susceptibility. From this framework, we can begin to determine the trait axes that are most associated with pathogen susceptibility. The first two axes of the PCA explained $75.9 \%$ of the total variation. Axis 1 was significantly associated with SLA $(\mathrm{r}=0.91 ; \mathrm{P}<0.01)$ and leaf nitrogen $(\mathrm{r}=0.66 ; \mathrm{P}=0.03)$. Axis 2 was significantly associated with leaf mass $(\mathrm{r}=0.90 ; \mathrm{P}<0.01)$, vegetative height $(\mathrm{r}=0.90 ; \mathrm{P}<0.01)$, and seed mass $(\mathrm{r}=0.82 ; \mathrm{P}<$ 0.01). Pathogen susceptibility was most strongly associated with Axis 2 of the PCA $(\mathrm{r}=0.55 ; \mathrm{P}=0.08)$. Therefore, we can hypothesize that taller invasive plants with larger leaves and seeds are more susceptible to pathogens, and recommend methods to test this hypothesis by expanding and improving the model in the future (Box 2).

Increasing the availability of both trait data and pathogen susceptibility data will help to refine this model. There is a particular need for additional data on root traits, for which there were none available for enough species to use in the analysis, despite the recent creation of a root specific trait database incorporated into the TRY database (Iversenet al. 2017). It is also important to note that this model does not necessarily imply direct causation of the traits correlated with pathogen effect but instead is meant to be predictive.

\section{Future directions}

The creation of trait databases (e.g. TRY, BiolFlor, FRED) and the use of trait based approaches have enhanced the ecologists' ability to investigate the importance of plant traits in numerous ecological processes and increasing information added to these databases will help improve the accuracy of our model in the future. Further information on novel pathogen attack of invaders will also help improve the model and make headway on answering further questions (see Fig. 3 and Table 3).

\section{Conclusions}

Once an invader reaches a high level of abundance eradication becomes very difficult or impossible. This means that time and resources are continually required to manage widespread invaders. Native pathogens could provide a low cost method for controlling some invaders if effective pathogens can be identified (Kotzé et al. 2015). Using our proposed framework, we aim to help predict what invaders are most susceptible to pathogens and therefore have the potential to be managed with native pathogens. This management can be accomplished with bioaugmentation of pathogens as microbial herbicides, a method that is currently used for a limited number of native pathogen-invasive plant combinations (Trognitzet al. 2016).

As debate continues surrounding the idea that native pathogens can control invasive plant populations and possibly reverse negative ecological effects, we suggest that a better understanding of the factors that predispose invaders to pathogen decline will improve monitoring and management efforts (Flory et al.2018; Policelli et al. 2018). Plant traits can determine pathogen tolerance and resistance to disease, so, logically, 
invader traits should provide some power to predict pathogen accumulation. There are many traits that are correlated with susceptibility of plants to disease, but more studies are needed assessing the interspecific variation in traits and plant pathogen attack, particularly among invasive species. We found evidence for 20 cases of invasive plant impacts due to novel pathogen interactions, but we expect that there are additional cases that remain unidentified due to limited research, for example where the etiology of disease has not been identified as with most plant-soil feedback studies (Diez et al. 2010). Additionally, most of these examples were variable in their effects on invader populations in the field so it is possible that cases with insufficient population monitoring of invaders may be overlooked. These cases could be important for management from a bioaugmentation perspective, where native diseases are augmented on susceptible invaders to provide control. As long-term research on invasive plants accumulates, this framework allows us to leverage these data to better understand patterns in dynamics of novel interactions with pathogens and their potential to control invader populations.

\title{
Acknowledgements
}

We thank Dr. Hafiz Maherali for his valuable feedback on earlier versions of this manuscript. This work was supported by a Discovery grant (RGPIN-2015-06060) from the Natural Sciences and Engineering Council of Canada and a Canada Research Chair to PMA. This research was conducted in Robinson-Huron Treaty territory and the traditional territory of the Anishnaabeg, specifically the Garden River and Batchewana First Nations, as well as Métis People.

Tables and Figures

Table 1. A list of traits which influence plant resistance and/or tolerance to pathogens.

\author{
Traits \\ Whole plant \\ Plant growth form \\ Plant lifespan \\ Nutrient content \\ Plant height \\ Plant growth rate \\ Canopy

\section{Defense} \\ Plant secondary compounds \\ Plant physical defense mechanisms \\ Defense priming \\ Leaf characteristics \\ Leaf size, cuticle size \\ Stomata \\ Leaf expansion rate \\ Leaf mass per area (LMA) \\ Shoot traits \\ Wood traits \\ Bark \\ Stem traits \\ Plant diameter \\ Reproductive traits \\ Seed traits \\ Dispersal \\ Flower \\ Plant propagation type \\ Fruit

\section{Mechanisms of increased resistance or tolerance} \\ Architecture, branching, reiteration, leaf density, leaf arrangement, determinant grow \\ Annuals support fewer pathogens than perennials \\ Plants with high nutrient contents are more susceptible to pathogens \\ Increased stem height and vertical elongation slow disease progression \\ Slow growth rate (trade off with growth and resistance) \\ Shorter narrower canopy \\ Production of cytokinins, flavonoids, phenols, $\mathrm{H}_{2} \mathrm{O}_{2}$, glucosynolates, non-protein ami \\ Papillae, lignin, silicon, dense trichomes \\ Plants with inducible defense are more resistant to pathogens \\ Thickened leaf cuticle and epidermis can provide physical resistance against fungal p \\ Lower stomatal density and stomatal index, stomatal function (closure) \\ Faster leaf expansion \\ Higher LMA, less airspace, and smaller cell sizes. \\ Higher wood density, higher parenchyma fraction, smaller xylem ray width and vesse \\ Smooth bark may decrease insect vectored pathogens \\ Narrow scattered vessels \\ Midrange peak in resistance with stem diameter \\ Small seeds, fast germination, hard seeds, shade tolerant species \\ Greater dispersal distances \\ Flower duration, Flower age, Style length, Nectar sugar concentration, Nectar sugar \\ Sexual reproduction increases genetic diversity \\ Physical protection, smaller fruit
}


Species genotype (chromosome)

Plant ontogeny

\section{Root traits}

Root biomass

Surface area

Root growth rate and lifespan

Root diameter

Symbiosis

Mycorrhiza

Endophytes

Vectors (pollinators and herbivores)

Rhizosphere bacteria

Other

Species occurrence range

Species habitat

Formation of monospecific stand
Higher ploidy

Early senescence reduces disease outbreaks

Roots can serve as storage organs for regrowth after aboveground damage

Higher root surface area higher disease resistance

Faster growth and higher turnover, thin, low nitrogen content

Larger diameter and biomass of secondary roots

Plants forming mycorrhizal associations show more resistance against pathogen infect Endophytes can induce resistance

Types of pollinators can affect transport of different pathogens. For instance, special Induce resistance to pathogens

pathogen richness was associated with range size for introduced plants.

Plants that occur in dry habitats have fewer pathogens than those in wet areas Plants forming monospecific stands are more susceptible to pathogens

Table 2. Examples of invasive plant decline due to native pathogens. We have maintained the naming system used in the references, but see footnotes for updated names. Globally distributed pathogens of unknown origin are shown in bold.

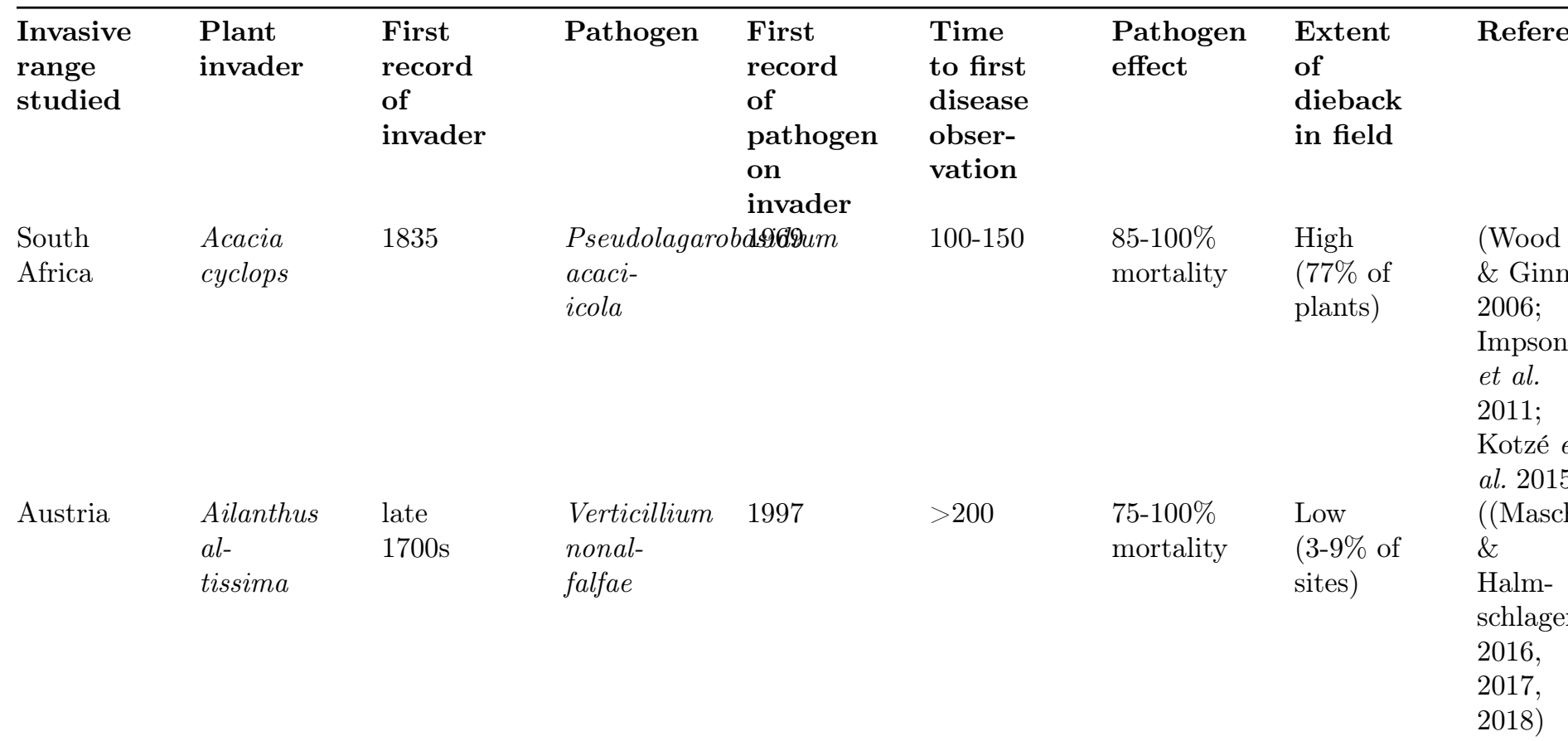




\begin{tabular}{|c|c|c|c|c|c|c|c|c|}
\hline USA & $\begin{array}{l}\text { Ailanthus } \\
\text { al- } \\
\text { tissima }\end{array}$ & 1784 & $\begin{array}{l}\text { Verticillium } \\
\text { nonal- } \\
\text { falfae }\end{array}$ & 1915 & $100-150$ & $\begin{array}{l}\text { 70-100\% } \\
\text { mortality }\end{array}$ & $\begin{array}{l}\text { High } \\
(66 \% \text { of } \\
\text { trees } \\
\text { infected; } \\
47 \% \\
\text { dead })\end{array}$ & $\begin{array}{l}\text { (Schall } \\
\text { \& Davi } \\
2009 \text {; } \\
\text { Kasson } \\
\text { et al. } \\
2014 \text {; } \\
\text { O'Neal } \\
\text { \& Davi } \\
2015 \text {; } \\
\text { Brooks } \\
\text { et al. } \\
2020 \text { ) }\end{array}$ \\
\hline USA & $\begin{array}{l}\text { Alliaria } \\
\text { petiolata }\end{array}$ & $1868-1890$ & $\begin{array}{l}\text { Erysiphe } \\
\text { cruciferarum }\end{array}$ & 2001 & $100-150$ & $\begin{array}{l}100 \% \\
\text { mortality; } \\
50 \% \\
\text { reduction } \\
\text { in seed } \\
\text { production }\end{array}$ & $\begin{array}{l}\text { Low }(30 \% \\
\text { of } \\
\text { populations } \\
\text { susceptible) }\end{array}$ & $\begin{array}{l}\text { (Blosse } \\
\text { al. } 200 \\
\text { Enright } \\
\text { Cipolli } \\
2007 ; \\
\text { Cipolli } \\
\text { Enright } \\
2009 ; \\
\text { Cipolli } \\
\text { al } 202\end{array}$ \\
\hline Hungary & $\begin{array}{l}\text { Ambrosia } \\
\text { artemisi- } \\
\text { ifolia }\end{array}$ & $1920 \mathrm{~s}$ & $\begin{array}{l}\text { Septoria } \\
\text { epam- } \\
\text { brosiae } \\
\text { sp. nov. }\end{array}$ & 1997 & $<100$ & $\begin{array}{l}\text { leaves } \\
\text { necrotic } \\
\text { and } \\
\text { occa- } \\
\text { sionally } \\
\text { plant } \\
\text { death }\end{array}$ & $\begin{array}{l}\text { Limited } \\
\text { research }\end{array}$ & $\begin{array}{l}\text { (Bohár } \\
\& \\
\text { Schwar } \\
\text { czinger } \\
1999 ; \\
\text { Farr \& } \\
\text { Castle- } \\
\text { bury } \\
2001)\end{array}$ \\
\hline Hungary & $\begin{array}{l}\text { Asclepias } \\
\text { syriaca }\end{array}$ & 1737 & $\begin{array}{l}\text { Fusarium } \\
\text { sporotrichioide }\end{array}$ & $\begin{array}{l}2016 \\
\text { s }\end{array}$ & $>200$ & $\begin{array}{l}\text { disease } \\
\text { symp- } \\
\text { toms } \\
\text { and no } \\
\text { seed } \\
\text { production }\end{array}$ & $\begin{array}{l}\text { Limited } \\
\text { research }\end{array}$ & $\begin{array}{l}\text { (Tóth } \\
\text { al. } 2018\end{array}$ \\
\hline USA & $\begin{array}{l}\text { Bromus } \\
\text { tecto- } \\
\text { rum }\end{array}$ & $\begin{array}{l}1860 \mathrm{~s} \text { to } \\
1890 \mathrm{~s}\end{array}$ & $\begin{array}{l}\text { Pyrenophora } \\
\text { se- } \\
\text { meniperda }\end{array}$ & 2000 & $100-150$ & $\begin{array}{l}7-50 \% \\
\text { seed } \\
\text { mortality }\end{array}$ & $\begin{array}{l}\text { Low } \\
(23 \% \\
\text { field } \\
\text { killed } \\
\text { seeds })\end{array}$ & $\begin{array}{l}\text { (Beckst } \\
\text { et al. } \\
2007 \text {; } \\
\text { Meyer } \\
\text { et al. } \\
2008 \text {, } \\
2016 \text {; } \\
\text { Morde- } \\
\text { cai } \\
2013 \text { ) }\end{array}$ \\
\hline
\end{tabular}




\begin{tabular}{|c|c|c|c|c|c|c|c|c|}
\hline USA & $\begin{array}{l}\text { Bromus } \\
\text { tecto- } \\
\text { rum }\end{array}$ & $\begin{array}{l}1860 \mathrm{~s} \text { to } \\
1890 \mathrm{~s}\end{array}$ & $\begin{array}{l}\text { Ustilago } \\
\text { bullata }\end{array}$ & 1937 & $<100$ & $\begin{array}{l}\sim 60 \% \\
\text { infection } \\
\text { rate }\end{array}$ & $\begin{array}{l}\text { Moderate } \\
(26-60 \% \\
\text { of plots })\end{array}$ & $\begin{array}{l}\text { (Fische } \\
1937 ; \\
\text { Meyer } \\
\text { et al. } \\
2001 \text {, } \\
2008 ; \\
\text { Prevéy } \\
\text { \& } \\
\text { Seasted } \\
\text { 2015) }\end{array}$ \\
\hline USA & $\begin{array}{l}\text { Centaurea } \\
\text { macu- } \\
\text { losa* }^{*}\end{array}$ & $\begin{array}{l}\text { late } \\
1800 \mathrm{~s}\end{array}$ & $\begin{array}{l}\text { Pseudomonas } \\
\text { syringae } \\
\text { pv. sy- } \\
\text { ringae }\end{array}$ & 1995 & $100-150$ & $\begin{array}{l}\text { stem } \\
\text { necrosis } \\
\text { and } \\
\text { dieback }\end{array}$ & $\begin{array}{l}\text { Low } \\
\text { ( } 36 \% \text { of } \\
\text { plants) }\end{array}$ & $\begin{array}{l}\text { (Kearin } \\
1996 ; \\
\text { Kearing } \\
\text { et al. } \\
\text { 1997) }\end{array}$ \\
\hline USA & $\begin{array}{l}\text { Centaurea } \\
\text { macu- } \\
\text { losa }^{*}\end{array}$ & $\begin{array}{l}\text { late } \\
1800 \mathrm{~s}\end{array}$ & $\begin{array}{l}\text { Sclerotinia } \\
\text { sclero- } \\
\text { tiorum }\end{array}$ & 1971 & $<100$ & $\begin{array}{l}0-100 \% \\
\text { mortality }\end{array}$ & $\begin{array}{l}\text { High } \\
(60-80 \% \\
\text { reduc- } \\
\text { tion in } \\
\text { density })\end{array}$ & $\begin{array}{l}\text { (Jacobs } \\
\text { et al. } \\
\text { 1996; } \\
\text { Ride- } \\
\text { nour \& } \\
\text { Call- } \\
\text { away } \\
2003 ; \\
\text { García } \\
\text { De la } \\
\text { Cruz et } \\
\text { al. } 2018\end{array}$ \\
\hline USA & $\begin{array}{l}\text { Centaurea } \\
\text { diffusa }\end{array}$ & 1907 & $\begin{array}{l}\text { Sclerotinia } \\
\text { sclero- } \\
\text { tiorum }\end{array}$ & 1971 & $<100$ & $\begin{array}{l}\text { Disease } \\
\text { symptoms }\end{array}$ & $\begin{array}{l}\text { Limited } \\
\text { research }\end{array}$ & $\begin{array}{l}\text { (Watso } \\
\text { et al. } \\
1974 \text { ) }\end{array}$ \\
\hline $\begin{array}{l}\text { South } \\
\text { Africa }\end{array}$ & $\begin{array}{l}\text { Hakea } \\
\text { sericea }\end{array}$ & 1858 & $\begin{array}{l}\text { Colletotrichum } \\
\text { gloeospo- } \\
\text { ri- } \\
\text { oides** }\end{array}$ & 21969 & $100-150$ & $\begin{array}{l}30-98 \% \\
\text { mortality }\end{array}$ & $\begin{array}{l}\text { High } \\
\text { (pre- } \\
\text { dicted } \\
82 \% \\
\text { decrease) }\end{array}$ & $\begin{array}{l}\text { (Richar } \\
\& \\
\text { Mander } \\
\text { 1985; } \\
\text { Morris } \\
\text { 1989, } \\
\text { 1991; } \\
\text { Gordon } \\
\text { 1999; } \\
\text { Esler et } \\
\text { al. } \\
2010 \text { ) }\end{array}$ \\
\hline
\end{tabular}




\begin{tabular}{|c|c|c|c|c|c|c|c|}
\hline USA & $\begin{array}{l}\text { Lonicera } \\
\text { maackii }\end{array}$ & 1898 & $\begin{array}{l}\text { Insolibasidium } 2012 \\
\text { defor- } \\
\text { mans }\end{array}$ & $100-150$ & $\begin{array}{l}50 \% \text { in- } \\
\text { fection; } \\
60-83 \% \\
\text { decrease } \\
\text { in } \\
\text { relative } \\
\text { growth } \\
\text { rate }\end{array}$ & $\begin{array}{l}\text { Moderate } \\
(62 \%, \\
30 \% \\
\text { dead } \\
\text { stems })\end{array}$ & $\begin{array}{l}\text { (Cunni } \\
\& \\
\text { Pascoe } \\
2003 ; \\
\text { Boyce } \\
\text { al. } \\
2014, \\
2020 ; \\
\text { Boyce } \\
2018 ; \\
\text { Klinge- } \\
\text { man et } \\
\text { al. } \\
2019 \text { ) }\end{array}$ \\
\hline USA & $\begin{array}{l}\text { Lythrum } \\
\text { salicaria }\end{array}$ & $\begin{array}{l}1920- \\
1939\end{array}$ & $\begin{array}{l}\text { Peyronellaea } 2014 \\
\text { glomerata }\end{array}$ & $<100$ & $\begin{array}{l}64 \% \\
\text { mortality }\end{array}$ & $\begin{array}{l}\text { Limited } \\
\text { research }\end{array}$ & $\begin{array}{l}\text { (Crocke } \\
\text { et al. } \\
2016)\end{array}$ \\
\hline USA & $\begin{array}{l}\text { Microstegium } \\
\text { vimineum }\end{array}$ & 1919 & $\begin{array}{l}\text { Bipolaris } \\
\text { sp. e.g } \\
\text { microstegii }\end{array}$ & $<100$ & $\begin{array}{l}40 \% \\
\text { decrease in } \\
\text { seed head } \\
\text { production }\end{array}$ & $\begin{array}{l}\text { Moderate } \\
(54 \% \text { of } \\
\text { sites })\end{array}$ & $\begin{array}{l}\text { (Klecze } \\
\text { \& Luke } \\
\text { Flory } 2 \\
\text { Flory e } \\
\text { 2011a; } \\
\text { Stricke } \\
\text { al. 201 } \\
\text { Brucka } \\
\text { al. 201 }\end{array}$ \\
\hline Australia & $\begin{array}{l}\text { Mimosa } \\
\text { pigra }\end{array}$ & 1891 & $\begin{array}{l}\text { Botryodiplodiał } 988 \\
\text { theobromae }\end{array}$ & $<100$ & $\begin{array}{l}35-85 \% \\
\text { mortality }\end{array}$ & $\begin{array}{l}\text { Moderate } \\
(52 \% \text { of } \\
\text { sites })\end{array}$ & $\begin{array}{l}\text { (Wilsor } \\
\& \\
\text { Pitketh } \\
\text { ley } \\
1992 ; \\
\text { Sac- } \\
\text { dalan } \\
2015 \text { ) }\end{array}$ \\
\hline USA & $\begin{array}{l}\text { Phragmites } \\
\text { australis }\end{array}$ & $\begin{array}{l}\text { before } \\
1900\end{array}$ & $\begin{array}{l}\text { Pythium } \\
\text { phragmitis }\end{array}$ & $100-150$ & $\begin{array}{l}100 \% \\
\text { mortality }\end{array}$ & $\begin{array}{l}\text { Limited } \\
\text { research }\end{array}$ & $\begin{array}{l}\text { (Crocke } \\
\text { et al. } \\
2015)\end{array}$ \\
\hline USA & $\begin{array}{l}\text { Phragmites } \\
\text { australis }\end{array}$ & $\begin{array}{l}\text { before } \\
1900\end{array}$ & $\begin{array}{l}\text { Fusarium } 2014 \\
\text { sporotrichioides }\end{array}$ & $100-150$ & $\begin{array}{l}100 \% \\
\text { mortality }\end{array}$ & $\begin{array}{l}\text { Limited } \\
\text { research }\end{array}$ & $\begin{array}{l}\text { (Crocke } \\
\text { et al. } \\
2016)\end{array}$ \\
\hline
\end{tabular}




\begin{tabular}{|c|c|c|c|c|c|c|c|c|}
\hline USA & $\begin{array}{l}\text { Rosa } \\
\text { multi- } \\
\text { flora }\end{array}$ & 1866 & $\begin{array}{l}\text { rose } \\
\text { rosette } \\
\text { disease } \\
\text { (Emaravirus) }\end{array}$ & 1961 & $<100$ & $\begin{array}{l}88-98 \% \\
\text { mortality }\end{array}$ & $\begin{array}{l}\text { High } \\
\text { (86\% in- } \\
\text { fection, } \\
36 \% \\
\text { decrease } \\
\text { in popu- } \\
\text { lation } \\
\text { density) }\end{array}$ & $\begin{array}{l}\text { (Amrin } \\
\text { et al. } \\
1990 ; \\
\text { Epstein } \\
\text { et al. } \\
1997 \text {; } \\
\text { Smith } \\
\text { al. } \\
2010 ; \text { D } \\
\text { Bello } e \\
\text { al. } \\
2015 \text {; } \\
\text { Pember } \\
\text { ton et } \\
\text { al. } \\
2018 \text { ) }\end{array}$ \\
\hline Australia & $\begin{array}{l}\text { Rubus } \\
\text { anglocandi- } \\
\text { cans }\end{array}$ & $\operatorname{mid} 1800 \mathrm{~s}$ & $\begin{array}{l}\text { Phytophthora } \\
\text { sp. e.g } \\
\text { bilorbang } \\
\text { sp. nov. }\end{array}$ & 2005 & $150-200$ & $\begin{array}{l}18-55 \% \\
\text { mortality }\end{array}$ & $\begin{array}{l}\text { High }(90 \% \\
\text { decrease in } \\
\text { cover) }\end{array}$ & $\begin{array}{l}\text { (Aghig) } \\
\text { al. } 201 \\
2014,2\end{array}$ \\
\hline
\end{tabular}

* syn. Centaurea stoebe ssp. micranthos

**Colletotrichum gloeosporioides has been renamed Colletotrichum acutatum f.sp. hakeae

${ }^{* * *}$ syn. Lasiodiplodia

Table 3. Directions for future research

Factors

Model accuracy

\author{
Research questions: \\ Proposed methods: \\ What is the accuracy of the \\ model developed in this review \\ when applied to additional \\ invasive species? Specific \\ challenges: How can we identify a \\ larger array of pathogens on \\ invaders including low impact \\ pathogens to improve the model? \\ Enhance reporting of pathogens \\ on invasive species by including \\ these data in invasive species \\ monitoring databases. \\ Experimentally test the impacts \\ of different known pathogens on \\ invaders with a range of traits, \\ specifically controlling for \\ pathogen traits as well as \\ inoculation rates to better control \\ for pathogen virulence. Isolate \\ microbial taxa from these plant \\ species. Identify potential \\ pathogens and use these to \\ re-infect plants to determine the \\ impacts of native pathogens.
}


Plant traits

Pathogen traits

Context dependence

Pathogen/plant trait interactions

Residence time
What are the mechanisms driving differences in pathogen susceptibility with plant traits? Specific challenges: Do native and invasive plants differ in SAR or defense priming? How do EM, $\mathrm{AM}$, and non-mycorrhizal invaders differ in their response to pathogens both above- and belowground?

What kinds of pathogens are most likely to cause invader decline?

How does incorporating context dependence improve the model? Specific challenges: How do plant/pathogen traits interact with environmental/abiotic conditions to influence disease susceptibility? How do inherent differences in plant tissue nutrient concentrations interact with environmental and habitat differences in nutrient availability? How do pathogen traits interact with plant traits to determine species combinations that will result in invader decline? Specific challenges: To what extent do allelopathic defense compounds affect pathogens with different traits? Does the type of pathogen influence whether annual species are less/more susceptible to pathogens than perennials? How do invader pathogen interactions change over time? Specific challenges: How long is a "weapon" of an invasive species "novel"? I.e. How long does it take for pathogens to evolve resistance to allelopathic chemicals of invaders in the novel range?
Decouple differences in correlated traits, for example, by testing disease susceptibility in genetically distinct populations of an invader. Compare across congeneric sets of native, non-native, and invasive plants. Expose invaders with different mycorrhiza status to a range of potential pathogens.

Collect data on pathogen traits and apply a similar model as developed for plant traits here to determine the most influential pathogen traits. Collect data on aspects of context dependence discussed previously and re-evaluate the model.

Combine models with pathogen traits and plant traits to determine interactions. Conduct bioassays using extracts from invasive plants comparing different pathogens such as generalists and specialists. Expose annual and perennial plants with a range of other traits to different types of pathogens (e.g. generalists vs. specialists). Survey pathogen impacts on populations of invaders across different residence times. Conduct bioassays using extracts from invasive plants collected along temporal gradients in invader residence time. 


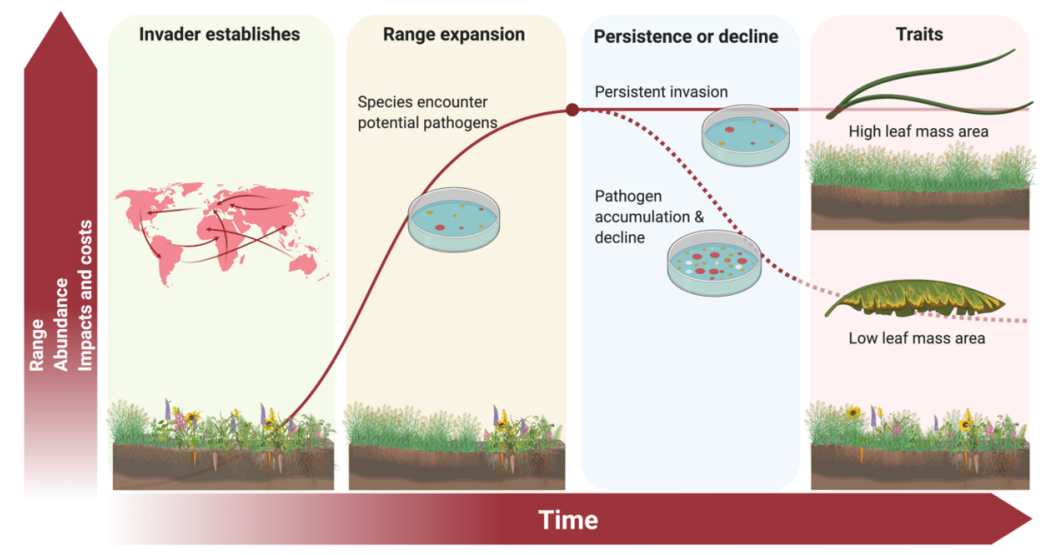

Figure 1. Of the pool of introduced non-native species a large majority do not establish. Of those that establish a small proportion of these become invasive and spread in the introduced range. Over time interactions with novel pathogens in the introduced range can cause the decline of some invaders. Understanding the traits that may contribute to pathogen susceptibility is an important goal to estimate the long-term consequences of plant invasions. Created with BioRender.com

\section{Hosted file}

image2.emf available at https://authorea.com/users/350529/articles/475347-susceptibility-ofnon-native-invasive-plants-to-novel-pathogen-attack-do-plant-traits-matter

Figure 2. Demonstration of a multivariate traits based approach to predict pathogen susceptibility of invasive plants. Species used as active observations in the principle components analysis are shown in grey and traits used as active variables are shown in blue. Pathogen effect as a supplemental variable is shown in red and supplemental species are shown in yellow.

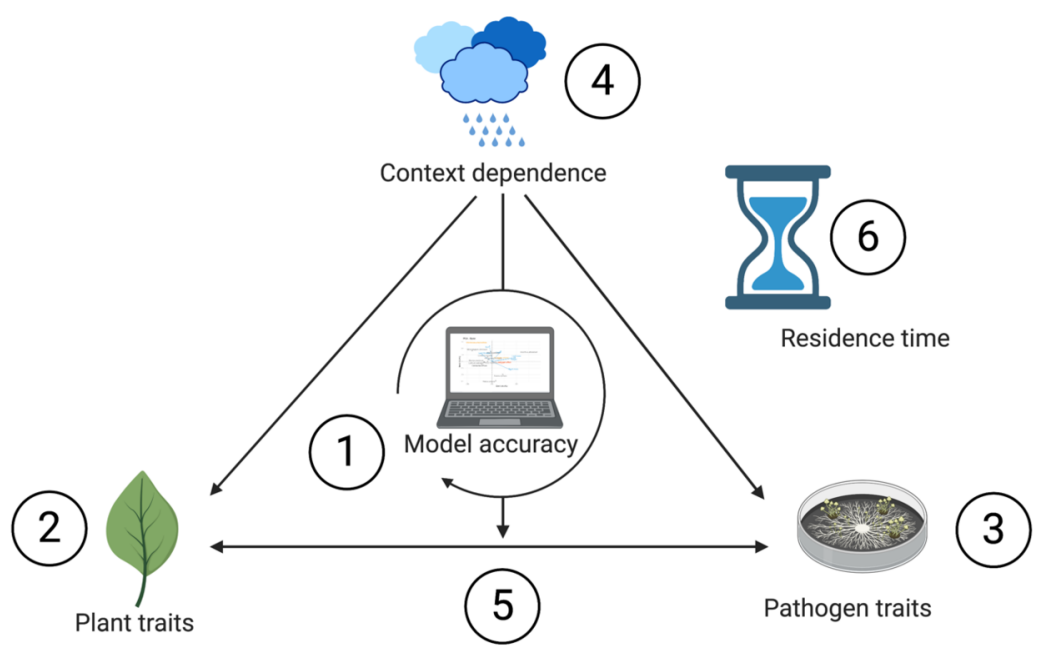


Figure 3. Factors involved in future research directions for predicting pathogen susceptibility that will result in invader decline: Model accuracy (1) is expected to increase as questions associated with plant traits (2), pathogen traits (3) and the influence of context dependence (4) on such traits either independently or through their interaction (5) are addressed. Furthermore, residence time (6) is a key component of future research (see Table 3 for a list of research questions).

Supplementary material

Table S1. Data used to calculate average pathogen effect on invasive plants.

\begin{tabular}{|c|c|c|c|}
\hline Plant invader & Pathogen & Effect of pathogen & \\
\hline \multirow[t]{2}{*}{ Acacia cyclops } & Pseudolagarobasidium acaciicola & 100.0 & $\%$ mortality (Wood \& \\
\hline & & 84.6 & $\%$ mortality (Kotze 201 \\
\hline \multirow[t]{3}{*}{ Ailanthus altissima } & Verticillium nonalfalfae & 85.0 & $\%$ mortality (Maschek \& \\
\hline & & 75.0 & $\%$ mortality (Maschek \& \\
\hline & & 100.0 & $\%$ mortality (Maschek \& \\
\hline \multirow[t]{4}{*}{ Ailanthus altissima } & Verticillium nonalfalfae & 100.0 & $\%$ mortality (Rebbeck et \\
\hline & & 100.0 & $\%$ mortality (AL Snyder \\
\hline & & 69.0 & $\%$ reduction in survival \\
\hline & & 100.0 & $\%$ mortality (O'Neal \& \\
\hline \multirow[t]{2}{*}{ Alliaria petiolata } & Erysiphe cruciferarum & 100.0 & $\%$ mortality (Enright \& \\
\hline & & 50.0 & $\%$ reduction in seed pr \\
\hline Ambrosia artemisiifolia & Septoria epambrosiae sp. nov. & NA & \\
\hline Asclepias syriaca & Fusarium sporotrichioides & NA & \\
\hline \multirow[t]{4}{*}{ Bromus tectorum } & Pyrenophora semeniperda & 51.7 & $\%$ reduction in seed sur \\
\hline & & 59.7 & $\%$ reduction in seed surv \\
\hline & & 20.3 & $\%$ seed mortality in no \\
\hline & & 11.1 & $\%$ seed mortality (Meyer \\
\hline \multirow[t]{3}{*}{ Bromus tectorum } & Ustilago bullata & 60.0 & $\%$ of plots with infection \\
\hline & & 3.5 & $\%$ reduction in seed prod \\
\hline & & 64.0 & infection rate (Meyer et \\
\hline Centaurea diffusa & Sclerotinia sclerotiorum & NA & \\
\hline \multirow[t]{2}{*}{ Centaurea stoebe ssp. micranthos } & Sclerotinia sclerotiorum & 66.7 & $\%$ mortality (Garcia de ] \\
\hline & & 100.0 & $\%$ mortality (Ridenour \& \\
\hline Centaurea stoebe ssp. micranthos & Pseudomonas syringae pv. syringae & NA & \\
\hline Hakea sericea & Colletotrichum gloeosporioides & 64.3 & \% mortality (Morris 198 \\
\hline \multirow[t]{2}{*}{ Lonicera maackii } & Insolibasidium deformans & 48.6 & $\%$ infection (Royce et al \\
\hline & & 71.5 & $\%$ decrease RGR (Royce \\
\hline Lythrum salicaria & Alternaria alternata & 48.0 & $\%$ mortality (Crocker 20 \\
\hline Lythrum salicaria & Peyronellaea glomerata & 64.0 & $\%$ mortality (Crocker 20 \\
\hline \multirow{2}{*}{ Microstegium vimineum } & Bipolaris sp. E.g microstegii & 40.0 & $\%$ reduction in seed hea \\
\hline & & 72.6 & $\%$ diseased leaves (Bruc \\
\hline Mimosa pigra & Botryodiplodia theobromae & 55.6 & $\%$ mortality (Sacdalan \\
\hline Phragmites australis & Pythium phragmites & 100.0 & $\%$ mortality (Crocker 2 \\
\hline Phragmites australis & Fusarium sporotrichioides & 100.0 & $\%$ mortality (Crocker 2 \\
\hline Phragmites australis & Alternaria alternata & 58.0 & $\%$ mortality (Crocker 2 \\
\hline Phragmites australis & Alternaria infectoria & 75.0 & $\%$ mortality (Crocker 2 \\
\hline Phragmites australis & Peyronellaea glomerata & 46.0 & $\%$ mortality (Crocker 2 \\
\hline Phragmites australis & Epicoccum nigrum & 51.0 & $\%$ mortality (Crocker 20 \\
\hline \multirow[t]{4}{*}{ Rosa multiflora } & rose rosette disease (Emaravirus) & 88.0 & $\%$ mortality (Amrine et \\
\hline & & 83.0 & $\%$ infection compared to \\
\hline & & 10.2 & $\%$ decrease in seed produ \\
\hline & & 98.0 & $\%$ mortality (O’Neal \& I \\
\hline
\end{tabular}




\section{References}

Aghighi, S., Burgess, T.I., Scott, J.K., Calver, M. \& Hardy, G.E.S.J. (2016). Isolation and pathogenicity of Phytophthora species from declining Rubus anglocandicans. Plant Pathol., 65, 451-461.

Aghighi, S., Fontanini, L., Yeoh, P.B., Hardy, G.E.S.J., Burgess, T.I. \& Scott, J.K. (2014). A conceptual model to describe the decline of European blackberry (Rubus anglocandicans), a weed of national significance in Australia. Plant Dis., 98, 580-589.

Aghighi, S., Hardy, G.E.S.J., Scott, J.K. \& Burgess, T.I. (2012). Phytophthora bilorbang sp. nov., a new species associated with the decline of Rubus anglocandicans (European blackberry) in Western Australia. Eur. J. Plant Pathol., 133, 841-855.

Agrawal, A.A. \& Kotanen, P.M. (2003). Herbivores and the success of exotic plants: a phylogenetically controlled experiment. Ecol Lett, 6, 712-715.

Akhtar, S.S., Mekureyaw, M.F., Pandey, C. \& Roitsch, T. (2020). Role of cytokinins for interactions of plants with microbial pathogens and pest insects. Front. Plant Sci., 10, 1777.

Alexander, H.M. (1984). Spatial patterns of disease induced by Fusarium moniliforme var. subglutinans in a population of Plantago lanceolata. Oecologia, 62, 141-143.

Alpert, P., Bone, E. \& Holzapfel, C. (2000). Invasiveness, invasibility and the role of environmental stress in the spread of non-native plants. Perspect. Plant Ecol. Evol. Syst., 3, 52-66.

Amrine, J.W., Jr., Hindal, D.F., Williams, R., Appel, J., Stasny, T. \& Kassar, A. (1990). Rose rosette as a biocontrol of multiflora rose, 1987-1989. In:Proceedings of the 43rd Annual Meeting of the Southern Weed Science Society. pp. 316-320.

Ando, K., Grumet, R., Terpstra, K. \& Kelly, J.D. (2007). Manipulation of plant architecture to enhance crop disease control. CAB Reviews: Perspectives in Agriculture, Veterinary Science, Nutrition and Natural Resources, 2, 8 .

Atucha, A., Emmett, B. \& Bauerle, T.L. (2014). Growth rate of fine root systems influences rootstock tolerance to replant disease. Plant Soil, 376, 337-346.

Augspurger, C.K. \& Kelly, C.K. (1984). Pathogen mortality of tropical tree seedlings: experimental studies of the effects of dispersal distance, seedling density, and light conditions. Oecologia, 61, 211-217.

Beckman, N.G. \& Muller-Landau, H.C. (2011). Linking fruit traits to variation in predispersal vertebrate seed predation, insect seed predation, and pathogen attack. Ecology, 92, 2131-2140.

Beckstead, J., Meyer, S.E., Molder, C.J. \& Smith, C. (2007). A race for survival: Can Bromus tectorum seeds escape Pyrenophora semeniperda-caused mortality by germinating quickly? Ann. Bot., 99, 907-914.

Beckstead, J., Meyer, S.E., Reinhart, K.O., Bergen, K.M., Holden, S.R. \& Boekweg, H.F. (2014). Factors affecting host range in a generalist seed pathogen of semi-arid shrublands. Plant Ecol., 215, 427-440.

Bednarek, P. \& Osbourn, A. (2009). Plant-microbe interactions: chemical diversity in plant defense.Science, $324,746-748$.

Bennett, R.N. \& Wallsgrove, R.M. (1994). Secondary metabolites in plant defence mechanisms.New Phytol., $127,617-633$.

Blossey, B. \& Notzold, R. (1995). Evolution of increased competitive ability in invasive nonindigenous plants: A hypothesis. J. Ecol., 83, 887-889. 
Blossey, B., Nuzzo, V., Hinz, H. \& Gerber, E. (2001). Developing biological control of Alliaria petiolata (M. Bieb.) Cavara and Grande (garlic mustard). Nat. Areas J., 21, 357-367.

Blumenthal, D., Mitchell, C.E., Pysek, P. \& Jarosík, V. (2009). Synergy between pathogen release and resource availability in plant invasion. Proc. Natl. Acad. Sci. U. S. A., 106, 7899-7904.

Boege, K., Dirzo, R., Siemens, D. \& Brown, P. (2007). Ontogenetic switches from plant resistance to tolerance: minimizing costs with age? Ecol. Lett., 10, 177-187.

Bohár, G. \& Schwarczinger, I. (1999). First report of a Septoria sp. on common ragweed (Ambrosia artemisiifolia) in Europe. Plant Dis., 83.

Borer, E.T., Hosseini, P.R., Seabloom, E.W. \& Dobson, A.P. (2007). Pathogen-induced reversal of native dominance in a grassland community. Proc. Natl. Acad. Sci. U. S. A., 104, 5473-5478.

Borowicz, V.A. (2001). Do arbuscular mycorrhizal fungi alter plant-pathogen relations?Ecology, 82, 30573068 .

Boyce, R.L. (2018). High mortality seen in open-grown, but not forest-understory, Amur honeysuckle (Lonicera maackii, Caprifoliaceae) stands in northern Kentucky. J. Torrey Bot. Soc., 145, 21-29.

Boyce, R.L., Brossart, S.N., Bryant, L.A., Fehrenbach, L.A., Hetzer, R., Holt, J.E., et al.(2014). The beginning of the end? Extensive dieback of an open-grown Amur honeysuckle stand in northern Kentucky, USA. Biol. Inv., 16, 2017-2023.

Boyce, R.L., Castellano, S.M., Marroquin, A.N., Uwolloh, O.M., Farrar, S.E. \& Wolfe, K.P. (2020). Honeysuckle leaf blight reduces the growth of infected Amur honeysuckle (Lonicera maackii, Caprifoliaceae) seedlings in a greenhouse experiment. J. Torrey Bot. Soc., 147, 1-8.

Bradley, D.J., Gilbert, G.S. \& Parker, I.M. (2003). Susceptibility of clover species to fungal infection: the interaction of leaf surface traits and environment.Am. J. Bot., 90, 857-864.

Brooks, R.K., Wickert, K.L., Baudoin, A., Kasson, M.T. \& Salom, S. (2020). Field-inoculatedAilanthus altissima stands reveal the biological control potential of Verticillium nonalfalfae in the mid-Atlantic region of the United States. Biol. Control, 148, 104298.

Bruckart, W.L., Eskandari, F.M., Michael, J.L. \& Smallwood, E.L. (2017). Differential aggressiveness of Bipolaris microstegii and B. drechslerion Japanese stiltgrass. Invasive Plant Sci. Manage., 10, 44-52.

Burdon, J.J. \& Chilvers, G.A. (1982). Host density as a factor in plant disease ecology. Annu. Rev. Phytopathol., 20, 143-166.

Burdon, J.J., Ericson, L. \& Muller, W.J. (1995). Temporal and spatial changes in a metapopulation of the rust pathogen Triphragmium ulmariae and its host,Filipendula ulmaria. J. Ecol., 83, 979-989.

Burdon, J.J., Jarosz, A.M. \& Kirby, G.C. (1989). Pattern and patchiness in plant-pathogen interactionsCauses and consequences. Ann. Rev.Ecol. Sys. 20, 119-136.

Busch, J.W., Neiman, M. \& Koslow, J.M. (2004). Evidence for maintenance of sex by pathogens in plants. Evol, 58, 2584-2590.

Carver, T.L.W. \& Gurr, S.J. (2008). Filamentous fungi on plant surfaces. In: Annual Plant Reviews Volume 23: Biology of the Plant Cuticle (eds. Riederer, M. \& Müller, C.). Blackwell Publishing Ltd, pp. 368-392.

Cazetta, E., Schaefer, H.M. \& Galetti, M. (2008). Does attraction to frugivores or defense against pathogens shape fruit pulp composition? Oecologia, 155, 277-286.

Chattopadhyay, S., Ali, K.A., Doss, S.G., Das, N.K., Aggarwal, R.K., Bandopadhyay, T.K., et al.(2011). Association of leaf micro-morphological characters with powdery mildew resistance in field-grown mulberry (Morus spp.) germplasm.AoB Plants, 2011, lr002. 
Cipollini, D., Davis, S., Lieurance, D., Cipollini, K. \& Bahn, V. (2020). Biogeographic variation in resistance of the invasive plant, Alliaria petiolata, to a powdery mildew fungus and effect of resistance on competitive dynamics.Biol. Inv., 22, 1657-1668.

Cipollini, D. \& Enright, S. (2009). A powdery mildew fungus levels the playing field for garlic mustard (Alliaria petiolata) and a North American native plant.Invasive Plant Sci. Manage., 2, 253-259.

Cipollini, M.L., Paulk, E., Mink, K., Vaughn, K. \& Fischer, T. (2004). Defense tradeoffs in fleshy fruits: Effects of resource variation on growth, reproduction, and fruit secondary chemistry in Solanum carolinense. J. Chem. Ecol., 30, 1-17.

Clay, K. (1995). Correlates of pathogen species richness in the grass family. Can. J. Bot., 73, 42-49.

Clay, K., Reinhart, K., Rudgers, J., Tintjer, T., Koslow, J. \& Flory, S.L. (2008). Red queen communities. In: Infectious Disease Ecology: Effects of Ecosystems on Disease and of Disease on Ecosystems (ed. Ostfeld, R.S.). Princeton University Press, Princeton, NJ, pp. 145-178.

Clay, K. \& Schardl, C. (2002). Evolutionary origins and ecological consequences of endophyte symbiosis with grasses. Am. Nat., 160 Suppl 4, S99-S127.

Cobb, F.W., Jr, Slaughter, G.W., Rowney, D.L. \& DeMars, C.J. (1982). Rate of spread ofCeratocystis wageneri in ponderosa pine stands in the central Sierra Nevada. Phytopathol., 72, 1359-1362.

Colautti, R.I. \& Barrett, S.C.H. (2013). Rapid adaptation to climate facilitates range expansion of an invasive plant. Science, 342, 364-366.

Colautti, R.I., Ricciardi, A., Grigorovich, I.A. \& MacIsaac, H.J. (2004). Is invasion success explained by the enemy release hypothesis? Ecol. Lett., 7, 721-733.

Coley, P.D., Bryant, J.P. \& Chapin, F.S., 3rd. (1985). Resource availability and plant antiherbivore defense. Science, 230, 895-899.

Connell, J.H. \& Lowman, M.D. (1989). Low-diversity tropical rain forests: Some possible mechanisms for their existence. Am. Nat., 134, 88-119.

Conrath, U., Beckers, G.J.M., Flors, V., García-Agustín, P., Jakab, G., Mauch, F., et al.(2006). Priming: Getting ready for battle. Mol. Plant. Microbe. Interact., 19, 1062-1071.

Costes, E., Lauri, P.E., Simon, S. \& Andrieu, B. (2013). Plant architecture, its diversity and manipulation in agronomic conditions, in relation with pest and pathogen attacks. Eur. J. Plant Pathol., 135, 455-470.

Crocker, E.V., Karp, M.A. \& Nelson, E.B. (2015). Virulence of oomycete pathogens fromPhragmites australisinvaded and noninvaded soils to seedlings of wetland plant species. Ecol. Evol., 5, 2127-2139.

Crocker, E.V., Lanzafane, J.J., Karp, M.A. \& Nelson, E.B. (2016). Overwintering seeds as reservoirs for seedling pathogens of wetland plant species.Ecosphere, 7, e01281.

Cronin, J.P., Rúa, M.A. \& Mitchell, C.E. (2014). Why Is living fast dangerous? Disentangling the roles of resistance and tolerance of disease. Am. Nat., 184, 172-187.

Cunnington, J.H. \& Pascoe, I.G. (2003). First record of Insolibasidium deformans in Australia. Australas. Plant Path., 32, 433.

Dalling, J.W., Davis, A.S., Schutte, B.J. \& Elizabeth Arnold, A. (2011). Seed survival in soil: interacting effects of predation, dormancy and the soil microbial community. J. Ecol., 99, 89-95.

De la Cruz, R.G., Knudsen, G.R., Carta, L.K. \& Newcombe, G. (2018). Either low inoculum or a multitrophic interaction can reduce the ability of Sclerotinia sclerotiorum to kill an invasive plant. Rhizosphere, $5,76-80$. 
Dempsey, D.A. \& Klessig, D.F. (2012). SOS-too many signals for systemic acquired resistance? Trends Plant Sci., 17, 538-545.

Di Bello, P.L., Ho, T. \& Tzanetakis, I.E. (2015). The evolution of emaraviruses is becoming more complex: Seven segments identified in the causal agent of Rose rosette disease. Virus Res., 210, 241-244.

Diez, J.M., Dickie, I., Edwards, G., Hulme, P.E., Sullivan, J.J. \& Duncan, R.P. (2010). Negative soil feedbacks accumulate over time for non-native plant species. Ecol. Lett., 13, 803-809.

Dini-Andreote, F. (2020). Endophytes: The second layer of plant defense. Trends Plant Sci., 25, 319-322.

Doherty, T.S., Glen, A.S., Nimmo, D.G., Ritchie, E.G. \& Dickman, C.R. (2016). Invasive predators and global biodiversity loss. PNAS, 113, 11261-11265.

Domínguez-Begines, J., Avila, J.M., Garcia, L.V. \& Gomez-Aparicio, L. (2020). Soil-borne pathogens as determinants of regeneration patterns at community level in Mediterranean forests. New Phytol., 227, 588600 .

Dordas, C. (2008). Role of nutrients in controlling plant diseases in sustainable agriculture. A review. Agron. Sustain. Dev., 28, 33-46.

Duchesne, L.C., Peterson, R.L. \& Ellis, B.E. (1989). The time-course of disease suppression and antibiosis by the ectomycorrhizal fungus Paxillus involutus.New Phytol., 111, 693-698.

Ďurkovič, J., Čaňová, I., Lagana, R., Kučerová, V., Moravčík, M., Priwitzer, T., et al.(2013). Leaf trait dissimilarities between Dutch elm hybrids with a contrasting tolerance to Dutch elm disease. Ann. Bot., 111, 215-227.

Durrer, S. \& Schmid-Hempel, P. (1994). Shared use of flowers leads to horizontal pathogen transmission. Proc. Roy. Soc B-Biol. Sci., 258, 299-302.

El-Hajj, Z., Kavanagh, K., Rose, C. \& Kanaan-Atallah, Z. (2004). Nitrogen and carbon dynamics of a foliar biotrophic fungal parasite in fertilized Douglas-fir. New Phytol., 163, 139-147.

Endara, M.-J. \& Coley, P.D. (2011). The resource availability hypothesis revisited: a meta-analysis.Funct. Ecol., 25, 389-398.

Enright, S.M. \& Cipollin, D. (2007). Infection by powdery mildew Erysiphe cruciferarum(Erysiphaceae) strongly affects growth and fitness of Alliaria petiolata (Brassicaceae). Am. J. Bot., 94, 1813-1820.

Epstein, A.H., Hill, J.H. \& Nutter, F.W. (1997). Augmentation of rose rosette disease for biocontrol of multiflora rose (Rosa multiflora). Weed Sci, 45, 172-178.

Erb, M., Lenk, C., Degenhardt, J. \& Turlings, T.C.J. (2009). The underestimated role of roots in defense against leaf attackers. Trends Plant Sci., 14, 653-659.

Esler, K.J., van Wilgen, B.W., te Roller, K.S., Wood, A.R. \& van der Merwe, J.H. (2010). A landscape-scale assessment of the long-term integrated control of an invasive shrub in South Africa. Biol. Inv., 12, 211-218.

Farr, D.F. \& Castlebury, L.A. (2001). Septoria epambrosiae sp. nov. on Ambrosia artemisiifolia (common ragweed). Sydowia, 53, 81-92.

Fernández-Escobar, R. (2019). Olive nutritional status and tolerance to biotic and abiotic stresses.Frontiers in Plant Science, 10, 1151.

Ferrari, M.J., Du, D., Winsor, J.A. \& Stephenson, A.G. (2007). Inbreeding depression of plant quality reduces incidence of an insect-borne pathogen in a wild gourd.Int. J. Plant Sci., 168, 603-610.

Ferrenberg, S. \& Mitton, J.B. (2014). Smooth bark surfaces can defend trees against insect attack: Resurrecting a "slippery" hypothesis. Funct. Ecol., 28, 837-845. 
Fischer, G.W. (1937). Observations on the comparative morphology and taxonomic relationships of certain grass smuts in western North America. Mycologia, 29, 408-425.

Flory, S.L., Alba, C., Clay, K., Holt, R.D. \& Goss, E.M. (2018). Emerging pathogens can suppress invaders and promote native species recovery. Biol. Inv., 20, 5-8.

Flory, S.L. \& Clay, K. (2013). Pathogen accumulation and long-term dynamics of plant invasions.J. Ecol., 101, 607-613.

Flory, S.L., Kleczewski, N. \& Clay, K. (2011a). Ecological consequences of pathogen accumulation on an invasive grass. Ecosphere, 2, 1-12.

Flory, S.L., Long, F. \& Clay, K. (2011b). Invasive Microstegium populations consistently outperform native range populations across diverse environments.Ecology, 92, 2248-2257.

Garcia De la Cruz, R., Knudsen, G.R., Carta, L.K. \& Newcombe, G. (2018). Either low inoculum or a multitrophic interaction can reduce the ability ofSclerotinia sclerotiorum to kill an invasive plant.Rhizosphere, 5 , $76-80$.

Garrett, S.D. (1956). Biology of root-infecting fungi. Soil Sci., 82, 97.

Gordon, A.J. (1999). A review of established and new insect agents for the biological control ofHakea sericea Schrader (Proteaceae) in South Africa.African Entomology Memoir , 1, 35-43.

Gruntman, M., Segev, U., Glauser, G. \& Tielborger, K. (2017). Evolution of plant defences along an invasion chronosequence: Defence is lost due to enemy release-but not forever. J. Ecol., 105, 255-264.

Haffner, E., Konietzki, S. \& Diederichsen, E. (2015). Keeping control: The role of senescence and development in plant pathogenesis and defense. Plants, 4, 449-488.

Handley, R.J., Steinger, T., Treier, U.A. \& Muller-Scharer, H. (2008). Testing the evolution of increased competitive ability (EICA) hypothesis in a novel framework.Ecology, 89, 407-417.

Hantsch, L., Braun, U., Haase, J., Purschke, O., Scherer-Lorenzen, M. \& Bruelheide, H. (2014). No plant functional diversity effects on foliar fungal pathogens in experimental tree communities. Fungal Divers., 66, $139-151$.

Harms, N., Shearer, J., Cronin, J.T. \& Gaskin, J.F. (2020). Geographic and genetic variation in susceptibility of Butomus umbellatus to foliar fungal pathogens.Biol. Inv., 22, 535-548.

Hawkes, C.V. (2007). Are invaders moving targets? The generality and persistence of advantages in size, reproduction, and enemy release in invasive plant species with time since introduction. Am. Nat., 170, 832-843.

Hejda, M., Pyšek, P. \& Jarosík, V. (2009). Impact of invasive plants on the species richness, diversity and composition of invaded communities. J. Ecol., 97, 393-403.

Herms, D.A. \& Mattson, W.J. (1992). The dilemma of plants: To grow or defend. Q. Rev. Biol., 67, 283-335.

Hilker, M., Schwachtje, J., Baier, M., Balazadeh, S., Bäurle, I., Geiselhardt, S., et al.(2016). Priming and memory of stress responses in organisms lacking a nervous system. Biol. Rev. Camb. Philos. Soc., 91, 11181133.

Hoffland, E., van Beusichem, M.L. \& Jeger, M.J. (1999). Nitrogen availability and susceptibility of tomato leaves to Botrytis cinerea. Plant Soil, 210, 263-272.

Hoffland, E., Jeger, M.J. \& van Beusichem, M.L. (2000). Effect of nitrogen supply rate on disease resistance in tomato depends on the pathogen. Plant Soil, 218, 239-247. 
Hoffland, E., Niemann, G.J., Van Pelt, J.A., Pureveen, J.B.M., Eijkel, G.B., Boon, J.J., et al. (1996). Relative growth rate correlates negatively with pathogen resistance in radish: The role of plant chemistry. Plant Cell Environ., 19, 1281-1290.

Howard, C., Flather, C.H. \& Stephens, P.A. (2020). A global assessment of the drivers of threatened terrestrial species richness. Nat. Commun., 11, 993.

Impson, F.A.C., Kleinjan, C.A., Hoffmann, J.H., Post, J.A. \& Wood, A.R. (2011). Biological control of Australian Acacia species and Paraserianthes lophantha (Willd.) Nielsen (Mimosaceae) in South Africa.Afr. Entomol., 19, 186-207.

Iversen, C.M., McCormack, M.L., Powell, A.S., Blackwood, C.B., Freschet, G.T., Kattge, J.,et al. (2017). A global fine-root ecology database to address below-ground challenges in plant ecology. New Phytol., 215, $15-26$.

Jacobs, J.S., Sheley, R.L. \& Maxwell, B.D. (1996). Effect of Sclerotinia sclerotiorum on the interference between bluebunch wheatgrass (Agropyron spicatum) and spotted knapweed (Centaurea maculosa). Weed Technol., 10, 13-21.

Jennersten, O., Nilsson, S.G., Wästljung, U. \& Wastljung, U. (1983). Local plant populations as ecological islands: The infection of Viscaria vulgaris by the fungus Ustilago violacea. Oikos, 41, 391.

Joshi, J. \& Vrieling, K. (2005). The enemy release and EICA hypothesis revisited: incorporating the fundamental difference between specialist and generalist herbivores.Ecol. Lett., 8, 704-714.

Josse, J., Husson, F. \& Others. (2016). missMDA: a package for handling missing values in multivariate data analysis. J. Stat. Softw., 70, 1-31.

Karban, R. (2011). The ecology and evolution of induced resistance against herbivores. Funct. Ecol., 25, $339-347$.

Kasson, M.T., Short, D.P.G., O’Neal, E.S., Subbarao, K.V. \& Davis, D.D. (2014). Comparative pathogenicity, biocontrol efficacy, and multilocus sequence typing of Verticillium nonalfalfae from the invasive Ailanthus altissima and other hosts. Phytopathol., 104, 282-292.

Kattge, J., Diaz, S., Lavorel, S., Prentice, I.C., Leadley, P., Bönisch, G., et al. (2011). TRY-a global database of plant traits. Glob. Chang. Biol., 17, 2905-2935.

Keane, R.M. \& Crawley, M.J. (2002). Exotic plant invasions and the enemy release hypothesis. Trends Ecol. Evol., 17, 164-170.

Kearing, S.A. (1996). Spotted knapweed (Centaurea maculosa Lam) : water, nutrients, plant competition, bacteria, and the seed head fly (Urophora affinisFrnfd.). Montana State University.

Kearing, S.A., Nowierski, R.M. \& Grey, W.E. (1997). First report of spotted knapweed (Centaurea maculosa) stem dieback caused by Pseudomonas syringae.Plant Dis., 81, 113.

Kleczewski, N.M. \& Luke Flory, S. (2010). Leaf blight disease on the invasive grassMicrostegium vimineum caused by a Bipolaris sp.Plant Dis., 94, 807-811.

van Kleunen, M. \& Fischer, M. (2009). Release from foliar and floral fungal pathogen species does not explain the geographic spread of naturalized North American plants in Europe. J. Ecol., 97, 385-392.

van Kleunen, M., Weber, E. \& Fischer, M. (2010). A meta-analysis of trait differences between invasive and non-invasive plant species. Ecol. Lett., 13, 235-245.

Klingeman, W.E., Bernard, E.C., Boggess, S.L., Pietsch, G.M., Hadziabdic, D. \& Trigiano, R.N. (2019). First report of honeysuckle leaf blight on Amur honeysuckle (Lonicera maackii) caused by Insolibasidium deformans in Tennessee. Plant Dis., 103. 
Kolkman, J.M. \& Kelly, J.D. (2002). Agronomic traits affecting resistance to white mold in common bean. Crop Sci., 42, 693-699.

Kotzé, L.J.D., Wood, A.R. \& Lennox, C.L. (2015). Risk assessment of the Acacia cyclopsdieback pathogen, Pseudolagarobasidium acaciicola, as a mycoherbicide in South African strandveld and limestone fynbos.Biol. Control, 82, 52-60.

Kramer-Walter, K.R., Bellingham, P.J., Millar, T.R., Smissen, R.D., Richardson, S.J. \& Laughlin, D.C. (2016). Root traits are multidimensional: specific root length is independent from root tissue density and the plant economic spectrum. J. Ecol., 104, 1299-1310.

Laliberté, E. (2017). Below-ground frontiers in trait-based plant ecology. New Phytol.

Laliberté, E., Lambers, H., Burgess, T.I. \& Joseph Wright, S. (2015). Phosphorus limitation, soil-borne pathogens and the coexistence of plant species in hyperdiverse forests and shrublands. New Phytol., 206, $507-521$.

Lambdon, P.W. \& Hulme, P.E. (2006). How strongly do interactions with closely-related native species influence plant invasions? Darwin's naturalization hypothesis assessed on Mediterranean islands. J. Biogeogr., $33,1116-1125$.

Leffler, A.J., James, J.J., Monaco, T.A. \& Sheley, R.L. (2014). A new perspective on trait differences between native and invasive exotic plants. Ecology, 95, 298-305.

Lê, S., Josse, J., Husson, F. \& Others. (2008). FactoMineR: an R package for multivariate analysis.J. Stat. Softw., 25, 1-18.

Levine, J.M., Vilà, M., D'Antonio, C.M., Dukes, J.S., Grigulis, K. \& Lavorel, S. (2003). Mechanisms underlying the impacts of exotic plant invasions.Proc. Roy. Soc. B-Biol. Sci., 270, 775-781.

Lewandowski, T.J., Dunfield, K.E. \& Antunes, P.M. (2013). Isolate identity determines plant tolerance to pathogen attack in assembled mycorrhizal communities.PLoS One, 8, e61329.

Liang, M., Johnson, D., Burslem, D.F.R.P., Yu, S., Fang, M., Taylor, J.D., et al. (2020). Soil fungal networks maintain local dominance of ectomycorrhizal trees.Nat. Commun., 11, 2636.

Li, C.X., Li, H., Sivasithamparam, K., Fu, T.D., Li, Y.C., Liu, S.Y., et al.(2006). Expression of field resistance under Western Australian conditions to Sclerotinia sclerotiorum in Chinese and AustralianBrassica napus and Brassica juncea germplasm and its relation with stem diameter. Aust. J. Agric. Res., 57, 1131-1135.

van Loon, L.C., Bakker, P.A.H.M. \& Pieterse, C.M.J. (1998). Systemic resistance induced by rhizosphere bacteria. Annu. Rev. Phytopathol., 36, 453-483.

Maherali, H. (2014). Is there an association between root architecture and mycorrhizal growth response? New Phytol., 204, 192-200.

Malamy, J., Carr, J.P., Klessig, D.F. \& Raskin, I. (1990). Salicylic Acid: a likely endogenous signal in the resistance response of tobacco to viral infection.Science, 250, 1002-1004.

Maron, J.L., Vilà, M., Bommarco, R., Elmendorf, S. \& Beardsley, P. (2004). Rapid evolution of an invasive plant. Ecol. Monogr., 74, 261-280.

Marquis, R.J., Diniz, I.R. \& Morais, H.C. (2001). Patterns and correlates of interspecific variation in foliar insect herbivory and pathogen attack in Brazilian cerrado.J. Trop. Ecol., 17, 127-148.

Marx, D.H. (1972). Ectomycorrhizae as biological deterrents to pathogenic root infections.Annu. Rev. Phytopathol., 10, 429-454.

Maschek, O. \& Halmschlager, E. (2016). First report of verticillium wilt on Ailanthus altissima in Europe caused by Verticillium nonalfalfae.Plant Dis., 100. 
Maschek, O. \& Halmschlager, E. (2017). Natural distribution of Verticillium wilt on invasiveAilanthus altissima in eastern Austria and its potential for biocontrol. Forest Pathol., 47, e12356.

Maschek, O. \& Halmschlager, E. (2018). Effects of Verticillium nonalfalfae on Ailanthus altissima and associated indigenous and invasive tree species in eastern Austria. Eur. J. For. Res., 137, 197-209.

Mauch-Mani, B. \& Mauch, F. (2005). The role of abscisic acid in plant-pathogen interactions.Curr. Opin. Plant Biol., 8, 409-414.

McArt, S.H., Koch, H., Irwin, R.E. \& Adler, L.S. (2014). Arranging the bouquet of disease: Floral traits and the transmission of plant and animal pathogens. Ecol. Lett., 17, 624-636.

McElrone, A.J., Reid, C.D., Hoye, K.A., Hart, E. \& Jackson, R.B. (2005). Elevated CO2 reduces disease incidence and severity of a red maple fungal pathogen via changes in host physiology and leaf chemistry. Glob. Chang. Biol., 11, 1828-1836.

Melotto, M., Underwood, W., Koczan, J., Nomura, K. \& He, S.Y. (2006). Plant stomata function in innate immunity against bacterial invasion. Cell, 126, 969-980.

Mendgen, K., Hahn, M. \& Deising, H. (1996). Morphogenesis and mechanisms of penetration by plant pathogenic fungi. Annu. Rev. Phytopathol., 34, 367-386.

Meyer, S.E., Beckstead, J. \& Pearce, J. (2016). Community Ecology of Fungal Pathogens on Bromus tectorum. In: Exotic Brome-Grasses in Arid and Semiarid Ecosystems of the Western US, Springer Series on Environmental Management (eds. Germino, M., Chambers, J. \& Brown, C.). Springer, pp. 193-223.

Meyer, S.E., Nelson, D.L. \& Clement, S. (2001). Evidence for resistance polymorphism in theBromus tectorum - Ustilago bullata pathosystem: Implications for biocontrol. Can. J. Plant Pathol., 23, 19-27.

Meyer, S.E., Nelson, D.L., Clement, S. \& Beckstead, J. (2008). Cheatgrass (Bromus tectorum) biocontrol using indigenous fungal pathogens. In:Proceedings-Shrublands under fire: disturbance and recovery in a changing world (eds. Kitchen, S.G., Pendleton, R.L., Monaco, T.A. \& Vernon, J.). U.S. Department of Agriculture, Forest Service, Rocky Mountain Research Station.

Mitchell, C.E., Blumenthal, D., Jarošík, V., Puckett, E.E. \& Pyšek, P. (2010). Controls on pathogen species richness in plants' introduced and native ranges: roles of residence time, range size and host traits. Ecol. Lett., 13, 1525-1535.

Mitchell, C.E. \& Power, A.G. (2003). Release of invasive plants from fungal and viral pathogens.Nature, 421, 625-627.

Mollot, G., Pantel, J.H. \& Romanuk, T.N. (2017). The effects of invasive species on the decline in species richness: a global meta-analysis. In: Advances in Ecological Research. Elsevier, pp. 61-83.

Mordecai, E.A. (2011). Pathogen impacts on plant communities: Unifying theory, concepts, and empirical work. Ecol. Monogr., 81, 429-441.

Mordecai, E.A. (2013). Despite spillover, a shared pathogen promotes native plant persistence in a cheatgrass-invaded grassland. Ecology, 94, 2744-2753.

Morris, H., Brodersen, C., Schwarze, F.W.M.R. \& Jansen, S. (2016). The parenchyma of secondary xylem and its critical role in tree defense against fungal decay in relation to the CODIT model. Front. Plant Sci., 7,1665 .

Morris, M.J. (1989). A method for controlling Hakea sericea Schrad. seedlings using the fungus Colletotrichum gloeosporioides (Penz.) Sacc. Weed Res., 29, 449-454.

Morris, M.J. (1991). The use of plant pathogens for biological weed control in South Africa.Agriculture, Ecosystems and Environment, 37, 239-255. 
Newsham, K.K., Fitter, A.H. \& Watkinson, A.R. (1995). Arbuscular mycorrhiza protect an annual grass from root pathogenic fungi in the field. J. Ecol., 83, 991-1000.

Noronha Souza, P.F., Abreu Oliveira, J.T., Vasconcelos, I.M., Magalhães, V.G., Albuquerque Silva, F.D., Guedes Silva, R.G., et al. (2020). $\mathrm{H}_{2} \mathrm{O}_{2}$ accumulation, host cell death and differential levels of proteins related to photosynthesis, redox homeostasis, and required for viral replication explain the resistance of EMS-mutagenized cowpea to cowpea severe mosaic virus. J. Plant Physiol., 245, 153110.

O'Neal, E.S. \& Davis, D.D. (2015). Intraspecific root grafts and clonal growth withinAilanthus altissima stands influence Verticillium nonalfalfae transmission. Plant Dis., 99.

Oswald, B.P. \& Nuismer, S.L. (2007). Neopolyploidy and pathogen resistance. Pro. Roy.Soc. B- Biol. Sci., 274, 2393-2397.

Packer, A. \& Clay, K. (2000). Soil pathogens and spatial patterns of seedling mortality in a temperate tree. Nature, 404, 278-281.

Parker, I.M. \& Gilbert, G.S. (2004). The evolutionary ecology of novel plant-pathogen interactions.Annu. Rev. Ecol. Evol. Syst., 35, 675-700.

Parker, I.M. \& Gilbert, G.S. (2007). When there is no escape: the effects of natural enemies on native, invasive, and noninvasive plants. Ecology, 88, 1210-1224.

Parker, I.M. \& Gilbert, G.S. (2018). Density-dependent disease, life-history trade-offs, and the effect of leaf pathogens on a suite of co-occurring close relatives.J. Ecol., 106, 1829-1838.

Parker, I.M., Saunders, M., Bontrager, M., Weitz, A.P., Hendricks, R., Magarey, R., et al.(2015). Phylogenetic structure and host abundance drive disease pressure in communities. Nature, 520, 542-544.

Parker, M.A. (1994). Pathogens and sex in plants. Evol. Ecol., 8, 560-584.

Pemberton, H.B., Ong, K., Windham, M., Olson, J. \& Byrne, D.H. (2018). What is rose rosette disease? HortScience, 53, 592-595.

Pimentel, D., Zuniga, R. \& Morrison, D. (2005). Update on the environmental and economic costs associated with alien-invasive species in the United States. Ecol. Econ., 52, 273-288.

Policelli, N., Chiuffo, M.C., Moyano, J., Torres, A., Rodriguez-Cabal, M.A. \& Nuñez, M.A. (2018). Pathogen accumulation cannot undo the impact of invasive species.Biol. Inv., 20, 1-4.

Pouzoulet, J., Pivovaroff, A.L., Santiago, L.S. \& Rolshausen, P.E. (2014). Can vessel dimension explain tolerance toward fungal vascular wilt diseases in woody plants? Lessons from dutch elm disease and esca disease in grapevine.Front. Plant Sci., 5, 253.

Pozo, M.J. \& Azcón-Aguilar, C. (2007). Unraveling mycorrhiza-induced resistance. Curr. Opin. Plant Biol., 10, 393-398.

Prentis, P.J., Wilson, J.R.U., Dormontt, E.E., Richardson, D.M. \& Lowe, A.J. (2008). Adaptive evolution in invasive species. Trends Plant Sci., 13, 288-294.

Prevéy, J.S. \& Seastedt, T.R. (2015). Increased winter precipitation benefits the native plant pathogen Ustilago bullata that infects an invasive grass.Biol. Inv., 17, 3041-3047.

Pringle, E.G., Álvarez-Loayza, P. \& Terborgh, J. (2007). Seed characteristics and susceptibility to pathogen attack in tree seeds of the Peruvian Amazon. Plant Ecol., 193, 211-222.

Pyšek, P., Jarošík, V., Hulme, P.E., Pergl, J., Hejda, M., Schaffner, U., et al. (2012). A global assessment of invasive plant impacts on resident species, communities and ecosystems: The interaction of impact measures, invading species' traits and environment. Glob. Chang. Biol., 18, 1725-1737. 
Pyšek, P. \& Richardson, D.M. (2008). Traits Associated with Invasiveness in Alien Plants: Where Do We Stand? In: Biological Invasions, Ecological Studies (Analysis and Synthesis) (ed. Nentwig, W.). Springer Berlin Heidelberg, Berlin, Heidelberg, pp. 97-125.

Pyšek, P., Richardson, D.M., Pergl, J., Jarošík, V., Sixtová, Z. \& Weber, E. (2008). Geographical and taxonomic biases in invasion ecology. Trends in Ecology 63 Evolution, 23, 237-244.

Reich, P.B. (2014). The world-wide "fast-slow" plant economics spectrum: a traits manifesto. J. Ecol., 102, 275-301.

Richardson, D.M. \& Manders, P.T. (1985). Predicting pathogen-induced mortality in Hakea sericea (Proteaceae), an aggressive alien plant invader in South Africa. Ann. Appl. Biol., 106, 243-254.

Ridenour, W.L. \& Callaway, R.M. (2003). Root herbivores, pathogenic fungi, and competition between Centaurea maculosa and Festuca idahoensis. Plant Ecol., 169, 161-170.

Robert, C., Garin, G., Abichou, M., Houles, V., Pradal, C. \& Fournier, C. (2018). Plant architecture and foliar senescence impact the race between wheat growth and Zymoseptoria tritici epidemics. Ann. Bot., 121, 975-989.

Roche, B.M., Alexander, H.M. \& Maltby, A.D. (1995). Dispersal and disease gradients of anther-smut infection of Silene alba at different life stages.Ecology, 76, 1863-1871.

Romero, C. \& Bolker, B.M. (2008). Effects of stem anatomical and structural traits on responses to stem damage: An experimental study in the Bolivian Amazon. Can. J. For. Res., 38, 611-618.

Sacdalan, A.D. (2015). Mimosa pigra dieback in the Northern Territory, Australia: Investigation into possible causes. The University of Queensland.

Salguero-Gomez, R., Jones, O.R., Jongejans, E., Blomberg, S.P., Hodgson, D.J., Mbeau-Ache, C., et al. (2016). Fast-slow continuum and reproductive strategies structure plant life-history variation worldwide. Proc. Natl. Acad. Sci. U. S. A., 113, 230-235.

Schall, M.J. \& Davis, D.D. (2009). Verticillium wilt of Ailanthus altissima: Susceptibility of associated tree species. Plant Dis., 93, 1158-1162.

Schardl, C.L., Leuchtmann, A. \& Spiering, M.J. (2004). Symbioses of grasses with seedborne fungal endophytes. Annu. Rev. Plant Biol., 55, 315-340.

Serrano, M., Coluccia, F., Torres, M., L'Haridon, F. \& Metraux, J.P. (2014). The cuticle and plant defense to pathogens. Front. Plant Sci., 5, 274.

Shykoff, J.A. \& Bucheli, E. (1995). Pollinator visitation patterns, floral rewards and the probability of transmission of Microbotryum violaceum, a veneral disease of plants. J. Ecol., 83, 189-198.

Shykoff, J.A., Bucheli, E. \& Kaltz, O. (1996). Flower lifespan and disease risk. Nature, 379, 779-779.

Sikes, B.A., Cottenie, K. \& Klironomos, J.N. (2009). Plant and fungal identity determines pathogen protection of plant roots by arbuscular mycorrhizas. J. Ecol., 97, 1274-1280.

Simberloff, D. \& Rejmanek, M. (2011). Encyclopedia of Biological Invasions. Encyclopedias of the Natural World. Univ of California Press.

Singh, J., Fabrizio, J., Desnoues, E., Silva, J.P., Busch, W. \& Khan, A. (2019). Root system traits impact early fire blight susceptibility in apple (Malus x domestica). BMC Plant Biol., 19, 579.

Smith, A.H., Potts, B.M., Ratkowsky, D.A., Pinkard, E.A. \& Mohammed, C.L. (2018). Association ofEucalyptus globulus leaf anatomy with susceptibility toTeratosphaeria leaf disease. For. Pathol., 48, e12395. 
Smith, L., de Lillo, E. \& Amrine, J.W. (2010). Effectiveness of eriophyid mites for biological control of weedy plants and challenges for future research. Exp. Appl. Acarol., 51, 115-149.

Snoeijers, S.S., Perez-Garcia, A., Joosten, M.H. \& De Wit, P.J. (2000). The effect of nitrogen on disease development and gene expression in bacterial and fungal plant pathogens. Eur. J. Plant Pathol., 106, 493-506.

Solla, A., Aguin, O., Cubera, E., Sampedro, L., Mansilla, J.P. \& Zas, R. (2011). Survival time analysis of Pinus pinaster inoculated with Armillaria ostoyae: Genetic variation and relevance of seed and root traits.Eur. J. Plant Pathol., 130, 477-488.

Solla, A., Martin, J.A., Corral, P. \& Gil, L. (2005). Seasonal changes in wood formation of Ulmus pumila and U. minor and its relation with Dutch elm disease. New Phytol., 166, 1025-1034.

Stack, R.W. (1975). Protection of Douglas-fir seedlings against Fusarium root rot by a mycorrhizal fungus in the absence of mycorrhiza formation.Phytopathology.

Stephenson, A.G. (2012). Safe sex in plants. New Phytol., 193, 827-829.

Stricker, K.B., Harmon, P.F., Goss, E.M., Clay, K. \& Luke Flory, S. (2016). Emergence and accumulation of novel pathogens suppress an invasive species. Ecol Lett., 19, 469-477.

Tamme, R., Gotzenberger, L., Zobel, M., Bullock, J.M., Hooftman, D.A.P., Kaasik, A., et al.(2014). Predicting species' maximum dispersal distances from simple plant traits. Ecology, 95, 505-513.

Thompson, K. \& Davis, M.A. (2011). Why research on traits of invasive plants tells us very little. Trends Ecol. Evol., 26, 155-156.

Thomson, F.J., Moles, A.T., Auld, T.D. \& Kingsford, R.T. (2011). Seed dispersal distance is more strongly correlated with plant height than with seed mass. J. Ecol., 99, 1299-1307.

Thrall, P.H., Biere, A. \& Antonovics, J. (1993). Plant life-history and disease susceptibility-the occurrence of Ustilago violacea on different species within the Caryophyllaceae. J. Ecol., 81, 489-498.

Torchin, M.E. \& Mitchell, C.E. (2004). Parasites, pathogens, and invasions by plants and animals.Front. Ecol. Environ., 2, 183-190.

Toth, T., Szilagyi, A. \& Kovics, G. (2018). Preliminary estimation of the efficacy ofFusarium sporotrichioides Sherb. as biological control agent against common milkweed (Asclepias syriaca L.). Acta Agraria Debreceniensis, 74, 201-204.

Trognitz, F., Hackl, E., Widhalm, S. \& Sessitsch, A. (2016). The role of plant-microbiome interactions in weed establishment and control. FEMS Microbiol. Ecol., 92.

Underwood, W. (2012). The plant cell wall: A dynamic barrier against pathogen invasion.Front. Plant Sci., 3,85 .

Valkama, E., Koricheva, J., Salminen, J.P., Helander, M., Saloniemi, I., Saikkonen, K., et al. (2005). Leaf surface traits: Overlooked determinants of birch resistance to herbivores and foliar micro-fungi? Trees, 19, 191-197.

Van Kleunen, M., Dawson, W., Schlaepfer, D., Jeschke, J.M. \& Fischer, M. (2010). Are invaders different? A conceptual framework of comparative approaches for assessing determinants of invasiveness. Ecol. Lett., 13, 947-958.

Van Wees, S.C.M., Van der Ent, S. \& Pieterse, C.M.J. (2008). Plant immune responses triggered by beneficial microbes. Curr. Opin. Plant Biol., 11, 443-448.

Veresoglou, S.D., Barto, E.K., Menexes, G. \& Rillig, M.C. (2013). Fertilization affects severity of disease caused by fungal plant pathogens. Plant Pathol., 62, 961-969. 
Vidal, T., Gigot, C., de Vallavieille-Pope, C., Huber, L. \& Saint-Jean, S. (2018). Contrasting plant height can improve the control of rain-borne diseases in wheat cultivar mixture: modelling splash dispersal in 3-D canopies. Ann. Bot., 121, 1299-1308.

Vila, M., Espinar, J.L., Hejda, M., Hulme, P.E., Jarošík, V., Maron, J.L., et al. (2011). Ecological impacts of invasive alien plants: a meta-analysis of their effects on species, communities and ecosystems. Ecol. Lett., 14, 702-708.

Vitousek, P.M., D’Antonio, C.M., Loope, L.L., Rejmánek, M. \& Westbrooks, R. (1997). Introduced species: A significant component of human-caused global change. N. Z. J. Ecol., 21, 1-16.

Walters, D.R. \& Bingham, I.J. (2007). Influence of nutrition on disease development caused by fungal pathogens: implications for plant disease control. Ann.Appl. Biol., 151, 307-324.

Watson, A.K., Copeman, R.J. \& Renney, A.J. (1974). A first record of Sclerotinia sclerotiorumand Microsphaeropsis centaureae on Centaurea diffusa.Can. J. Bot., 52, 2639-2640.

Wehner, J., Antunes, P.M., Powell, J.R., Caruso, T. \& Rillig, M.C. (2011). Indigenous arbuscular mycorrhizal fungal assemblages protect grassland host plants from pathogens. PLoS One, 6, e27381.

Welsh, M.E., Cronin, J.P. \& Mitchell, C.E. (2016). The role of habitat filtering in the leaf economics spectrum and plant susceptibility to pathogen infection.J. Ecol., 104, 1768-1777.

Whipps, J.M. (2004). Prospects and limitations for mycorrhizas in biocontrol of root pathogens. Can. J. Bot., $82,1198-1227$.

Wilson, C.G. \& Pitkethley, N.R. (1992). Botryodiplodia dieback of Mimosa pigra, a noxious weed in northern Australia. Plant Pathol., 41, 777-779.

Wood, A.R. \& Ginns, J. (2006). A new dieback disease of Acacia cyclops in South Africa caused by Pseudolagarobasidium acaciicola sp.nov. Can. J. Bot., 84, 750-758.

Wright, I.J., Reich, P.B., Westoby, M., Ackerly, D.D., Baruch, Z., Bongers, F., et al.(2004). The worldwide leaf economics spectrum. Nature, 428, 821-827.

Yanai, R.D. \& Eissenstat, D.M. (2002). Coping with herbivores and pathogens: A model of optimal root turnover. Funct. Ecol., 16, 865-869.

Zamioudis, C. \& Pieterse, C.M.J. (2012). Modulation of host immunity by beneficial microbes.Mol. Plant Microbe Interact., 25, 139-150.

Zhang, Q., Yang, R., Tang, J., Yang, H., Hu, S. \& Chen, X. (2010). Positive feedback between mycorrhizal fungi and plants influences plant invasion success and resistance to invasion. PLoS One, 5, e12380-e12380.

Zhang, S., Jin, Y., Tang, J. \& Chen, X. (2009). The invasive plant Solidago canadensis L. suppresses local soil pathogens through allelopathy. Appl. Soil Ecol., 41, 215-222.

Zúñiga, E., Luque, J. \& Martos, S. (2019). Lignin biosynthesis as a key mechanism to repressPolystigma amygdalinum, the causal agent of the red leaf blotch disease in almond. J. Plant Physiol., 236, 96-104. 